\title{
Phylogenetics and population genetics of Plotosus canius (Siluriformes: Plotosidae) from Malaysian coastal waters
}

Nima Khalili Samani, Yuzine Esa, S.M Nurul Amin, Natrah Fatin Mohd Ikhsan

Plotosus canius (Hamilton, 1822) is a significant marine species in Malaysia from nutritional and commercial perspectives. Despite numerous fundamental researches on biological characteristics of P.canius, there are various concerns on the level of population differentiation, genomic structure, and the level of genetic variability among their populations due to deficiency of genetic-based studies. Deficiency on basic contexts such as stock identification, phylogenetic relationship and population genetic structure would negatively impact their sustainable conservation. Hence, this study was conducted to characterize the genetic structure of P.canius for the first time through the application of mitochondrial Cytochrome Oxidase I (COI) gene, cross amplification of Tandanus tandanus microsatellites, and a total of 117 collected specimens across five selected populations of Malaysia. The experimental results of the mitochondrial analysis revealed that the haplotype diversity and nucleotide diversity varied from 0.395 to 0.771 and 0.033 to 0.65 respectively. Moreover, the statistical analysis of microsatellites addressed a considerable heterozygote insufficiency in all populations, with average observed heterozygosity $(\mathrm{HO})$ value of 0.2168 , which was lower than the standard heterozygosity in marine populations $(H O=0.79)$. This alongside the high Fis values estimation, high pairwise differentiation among populations and low within population variations are supposed to be associated with small sample size, and inbreeding system. Besides, the significant finding of this study was the sharing of common haplotype KR086940 at which reflects a historical genetic connectivity between Peninsular Malaysia and Borneo populations due to the geological history of Southeast Asia during Pleistocene era. Demographic analyses showed that all populations were in equilibrium state with no significant evidence of population expansion. To put it briefly, the current study has managed to provide an initial genomic database toward understanding of the genetic characterization, phylogenetic, molecular diversification and population structure in P.canius, and should be necessary highlighted for appropriate management and conservation of species. Though, further studies must be carried out involving more geographical and sampling sites, larger population size per site, and utilization of species specific microsatellites loci. 
1 Phylogenetics and Population Genetics of Plotosus canius (Siluriformes: Plotosidae) from

2

3

4

$18 *$ Corresponding Author:

$19 \quad$ Nima Khalili Samani

20 Graduate Researcher, Department of Aquaculture, Faculty of Agriculture

21 Universiti Putra Malaysia, 43400 Serdang, Selangor, Malaysia

22 nima.khalili.samani@gmail.com

23 Tel: +60129175937. Fax: +603-8940 8311

\section{Selangor, Malaysia}


24 ABSTRACT: Plotosus canius (Hamilton, 1822) is a significant marine species in Malaysia from 25 nutritional and commercial perspectives. Despite numerous fundamental researches on biological characteristics of P.canius, there are various concerns on the level of population differentiation, genomic structure, and the level of genetic variability among their populations due to deficiency of genetic-based studies. Deficiency on basic contexts such as stock identification, phylogenetic relationship and population genetic structure would negatively impact their sustainable conservation. Hence, this study was conducted to characterize the genetic structure of P.canius for the first time through the application of mitochondrial Cytochrome Oxidase I (COI) gene, cross amplification of Tandanus tandanus microsatellites, and a total of 117 collected specimens across five selected populations of Malaysia. The experimental results of the mitochondrial analysis revealed that the haplotype diversity and nucleotide diversity varied from 0.395 to 0.771 and 0.033 to 0.65 respectively. Moreover, the statistical analysis of microsatellites addressed a considerable heterozygote insufficiency in all populations, with average observed heterozygosity (HO) value of 0.2168 , which was lower than the standard heterozygosity in marine populations $(H O=0.79)$. This alongside the high Fis values estimation, high pairwise differentiation among populations and low within population variations are supposed to be associated with small sample size, and inbreeding system. Besides, the significant finding of this study was the sharing of common haplotype KR086940 at which reflects a historical genetic connectivity between Peninsular Malaysia and Borneo populations due to the geological history of Southeast Asia during Pleistocene era. Demographic analyses showed that all populations were in equilibrium state with no significant evidence of population expansion. To put it briefly, the current study has managed to provide an initial genomic database toward understanding of the genetic characterization, phylogenetic, molecular diversification and population structure in P.canius, and should be necessary highlighted for appropriate management and conservation of species. Though, further studies must be carried out involving more geographical and sampling sites, 


\section{INTRODUCTION}

55 Plotosus canius (Hamilton,1822) that is known as grey eel-catfish, black eel-tail catfish, canine catfish or Indian catfish (Khan et al., 2002; Riede, 2004; Usman et al., 2013; Prithiviraj, 2014), were diagnosed as a member of genus Plotosus, family Plotosidae (Froese \& Pauly, 2015). They are being mainly distributed in estuaries, freshwater rivers, lagoons, and shallow waters of Australia and Southeast Asia (Carpenter, 1999; Prithiviraj \& Annadurai, 2012). The species is an amphidromous and demersal bony fish that can live in marine, brackish and freshwater habitats. Their relocation in about $100 \mathrm{~km}$ range were described as cyclical and frequent horizontal movement on which could not be categorized as breeding migration (Riede, 2004). However, the species might be recently endured genetic destruction mostly due to overexploitation similar to other fish species (Pauly et al., 2002; Collette et al., 2011; Usman et al., 2013), their population structure could be considered as the reliable indicator in detection of sustainable and healthy marine environments (Thomsen et al., 2012; Bourlat et al., 2013).

Population structure is the direct consequence of biogeography (Leffler et al., 2012), which provides invaluable statistics on patterns of species dynamics, colonization, and isolation (Costello et al., 2003). As species become accustomed into new habitat, effective size of population extends through its dispersal, resulting in intensification of genetic variation (Charlesworth \& Willis, 2009). However, deterioration of environmental equations alongside with ecological fluctuations such as recent re-treatment of Pleistocene era have changed species extensive genetic patterns (Krishnamurthy \& Francis, 2012). Adding to complication, the accuracy of associated conservation strategies can be successively restrained by deficiency of reliable knowledge on biodiversity, conservation resolution, and extent of biological destruction among taxonomic levels (Wright et al., 2008; Butchart et al., 2010; Magurran et al., 2010; Pereira et al., 2010; Hoffmann et al., 2011). Such scarcities confidently offered a viable incentive to regulate the sustainable species variation ( Primack, 2002; Duvernell et al., 2008; Appeltans et al., 2012; Bourlat et al., 2013; Leray \& Knowlton, 2015) through advancing genomic protocols to challenge the genetic intimidations such as distraction of local traits, genetic drift and inbreeding effects (Tallmon et al., 2004). 
84 The same conservation obstacle is hypothetically threatening P.canius populations in Malaysia, 85 since there is not any comprehensive documentation nor a single initial research on their genetic characterization. Indeed, regarding to their regional significance in Oceania and Southeast Asia (Usman et al., 2013), a few regional studies have been merely carried out on basic biological perceptions of Plotosus canius including their morphology and fisheries (Kumar, 2012; Usman et al., 2013), fecundity (Khan et al., 2002; Usman et al., 2013), feeding behaviour (Leh et al., 2012), protein structure (Prithiviraj \& Annadurai, 2012) and pharmacology (Prithiviraj, 2014). Such deficiencies have raised some severe concerns on the level of population structure, genetic variation and the consequences of genetic differentiation among populations of P.canius especially in Malaysia. Thus, this study was performed to genetically characterize P.canius through the utilization of the mitochondrial Cytochrome Oxidase I (COI) gene and Tandanus tandanus microsatellites, in order to examine the accuracy of employed markers in phylogenetic study, genetic variation assignment, and population genetic structure of P.canius in Malaysia.

\section{MATERIALS AND METHODS}

100 Sample Collection and DNA Isolation

101

102

Total of 130 catfish samples demonstrating 2 species of family Plotosidae were directly collected including of 117 samples of Plotosus canius and 13 samples of Plotosus lineatus. Sample collection of P.canius were performed in 5 various districts throughout Malaysia including: Negeri Sembilan (NSN), Selangor (SGR), Johor (JHR), Sarawak (SWK) and Sabah (SBH) (Figure.1) from May to December 2014, while P.lineatus samples were only collected from Selangor. Sampling was carried out directly from fishermen in commercial fishing docks of Port Dickson (Negeri Sembilan), Kuala Selangor (Selangor), Kukup (Johor), Bintulu (Sarawak) and Putatan (Sabah). DNA extraction protocol was performed upon sample collection in laboratory 111 manufacturer's protocol instructions by using roughly $20 \mathrm{mg}$ of specimens. 
112

113

114

115

116

117

118

119

120

121

122

123

124

125

126

127

128

129

130

131

132

133

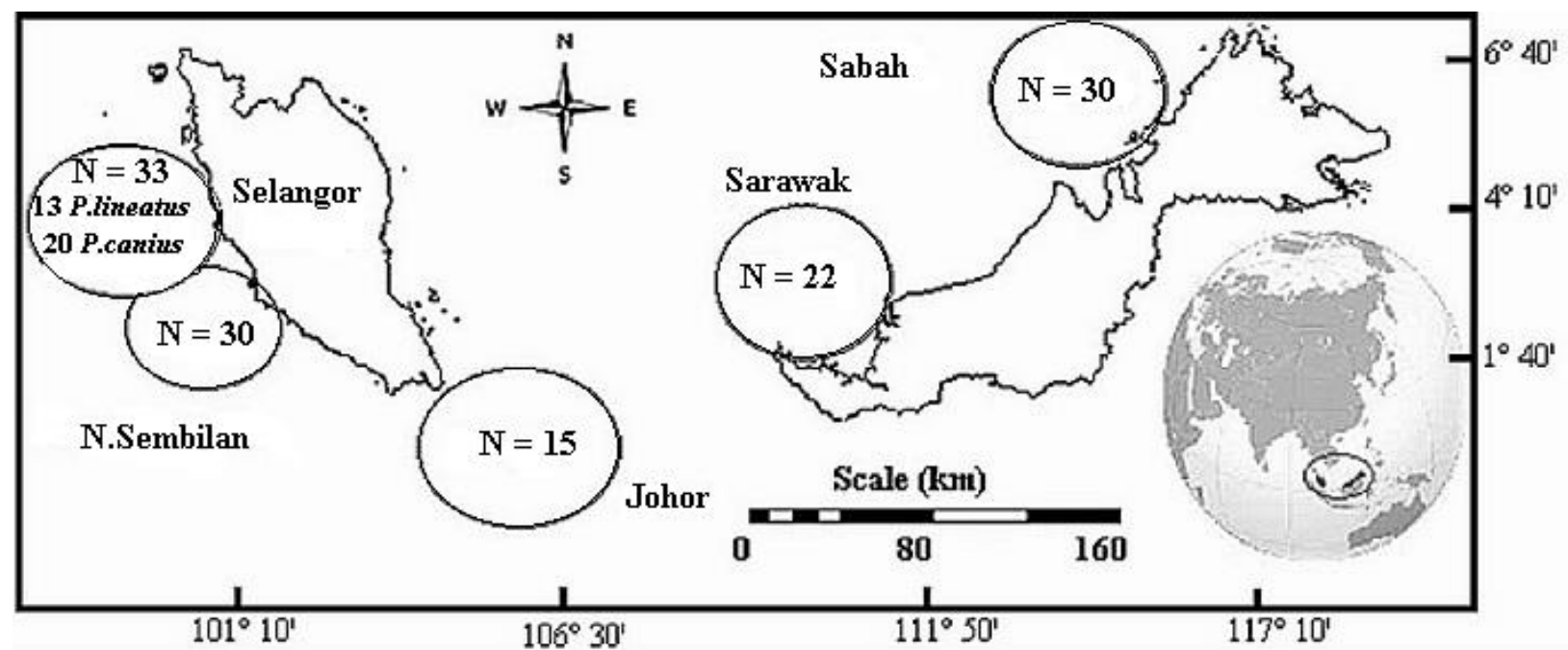

Figure. 1) Sampling sites and sample size (N) diagram of P.canius and P.lineatus in Malaysia.

\section{PCR Amplification and Sequencing of Mitochondrial DNA}

To accurately amplify a $655 \mathrm{bp}$ fragment of mitochondrial DNA, PCR amplification were performed by using C_Fish1 primer set (Ward et al., 2005) on the 5' end of COI gene. The amplification protocol were conducted in an overall volume of $25 \mu \mathrm{l}$ at which contained $0.6 \mu 1$ of each deoxynucleotide triphosphate (dNTPs), $0.7 \mu 1$ Taq polymerase, $1.2 \mu 1 \mathrm{MgCl} 2,0.25 \mu 1$ of each primers, $2 \mu \mathrm{l}$ of concentrated genomic DNA, $2.5 \mu \mathrm{l}$ of Taq buffer and $18 \mu \mathrm{l}$ of distilled $\mathrm{H} 2 \mathrm{O}$ as stated by Ward et al. 2005, with slight modification. The PCR reaction was carried out using an Eppendorf Mastercycler based on the following thermal regime: 2 min of $95{ }^{\circ} \mathrm{C}$ initial denaturation step; 35 cycles of $94{ }^{\circ} \mathrm{C}$ denaturation step for $30 \mathrm{~s}$, a $54{ }^{\circ} \mathrm{C}$ annealing temperature for $45 \mathrm{~s}$ and $\mathrm{a} 72^{\circ} \mathrm{C}$ extension period of $1 \mathrm{~min}$; followed by $72{ }^{\circ} \mathrm{C}$ final extension step for $10 \mathrm{~min}$ and a routine $4{ }^{\circ} \mathrm{C}$ final hold (Ward et al., 2005). In order to confirm that the PCR reaction generated sufficient amplicon proportions, PCR amplification products were visualized using a 2.0 per cent laboratory grade agarose gel containing $5 \mu \mathrm{l} \mathrm{GelRed} \mathrm{stain.} \mathrm{Amplified} \mathrm{products} \mathrm{were}$ subsequently isolated and purified upon their visualization and documentation. DNA purification from gel was commonly carried out using the Wizard ${ }^{\circ}$ SV Gel and PCR Clean-up System (Promega, USA). Purified DNA samples were finally sent to private sector institution ( $1^{\text {st }}$ Base laboratories Sdn Bhd) for sequencing to generate associated trace files and continuous read lengths intended for genetic and statistical analysis of mitochondrial DNA. 
134 Statistical Analysis of Mitochondrial DNA

135 Trace files were manually end-trimmed using BioEdit software 7.2.5 (Hall, 1999) regarding to 136 their homologous section. Afterwards, ClustalX 2.1 (Thompson et al., 1997) was applied to 137 progressively manipulate, align and analyze the DNA sequences. Finally, haplotypes were 138 detected with DnaSP software 5.10.01 (Librado \& Rozas, 2009) and deposited into 139 BOLDSYSTEM (international barcode of life) and GenBank.

140 To comparatively analyze mitochondrial DNA sequences, MEGA 6 program (Tamura et al., 141 2013) were used intending to understand the phylogenetic outlines of COI gene and species, 142 generate sequence alignment and perform evolutionary analysis. Calculation of the pairwise 143 distance was obtained through 1000 bootstrap variance estimation and Tamura-Nei model 144 (Tamura \& Nei, 1993). Moreover, overall mean nucleotide distance of sequences was computed 145 using same configuration at each codon positions separately. Subsequently, construction of 146 phylogenetic tree from the highest grade aligned sequences of P.canius and P.lineatus was 147 prompted in comparison to one haplotype of African sharp tooth catfish Clarias gariepinus 148 (ANGBF8254-12) from Thailand as an outgroup through Neighbor-Joining (NJ) and Maximum 149 Likelihood (ML) methods using a mutual 1000 replication bootstrap. Next, Minimum Spanning 150 Network (MSN) was computed using PopART (Bandelt et al., 1994) application among obtained 151 sequences of P.canius.

152 Extraction of genetic features from assembly of sequences based on some rudimentary 153 implemented analytical tests was performed through Arlequin software 3.5 (Excoffier et al., 154 2005). As the most crucial objective was to compute the genetic structure, hierarchical analysis 155 of molecular variance (AMOVA) and pairwise $F_{S T}$ values of chi square test, population 156 differentiation was successively calculated among five populations of P.canius in Malaysia. 157 Analysis of molecular variance was carried out using 1000 permutation to compute distance 158 matrix of sequences, while the same structure were implemented for comparison of all available 159 pair samples and populations through calculation of $F_{S T}$ with 0.05 significance level.

160 Demographic history was estimated using Tajima's D test (Tajima 1989) and Fu's Fs test (Fu 161 1997) to test the hypothesis of neutrality of the COI gene. A negative Tajima's D-values might 162 indicate bottleneck, selection or population expansion (Tajima, 1989). Mismatch distributions 163 test was also computed to evaluate the hypothesis of recent population expansion or growth 164 (Rogers \& Harpending, 1992). The distribution is commonly unimodal in populations that have 
165 undergone a recent demographic expansion, and is multimodal in stable or equilibrium

166 populations. All analyses were carried out using ARLEQUIN, while associated mismatch graphs

167 were obtained from DnaSP.

168

169

Microsatellite Genotyping

170

To run measured PCR protocol, optimization of PCR composition were performed at which made positive outcomes based on initial PCR regime using the main protocol for the

172 amplification of Tandanus tandanus (Rourke et al., 2010) with minor regulation in the amount

173 and concentration of primers, Taq DNA polymerase, $\mathrm{MgCl} 2$ and dNTPs to enhance the accuracy 174 of the protocol. However, the optimum annealing temperature were practically calculated $55^{\circ} \mathrm{C}$

175 similar as original species. To consciously amplify DNA fragments, PCR amplification were 176 performed by using five cross-amplified microsatellites of T.tandanus (Rourke et al., 2010; 177 Rourke \& Gilligan, 2010) on the 5' end, presented in Table.5. The feasible amplification 178 protocol were conducted in a total volume of $25 \mu \mathrm{l}$ solution inclosing $0.6 \mu 1$ of each 179 deoxynucleotide triphosphate (dNTPs), $0.7 \mu 1$ Taq DNA polymerase, $1.2 \mu 1 \mathrm{MgCl} 2,0.25 \mu 1$ of 180 each primers, $2 \mu \mathrm{l}$ of concentrated genomic DNA, $2.5 \mu \mathrm{l}$ of Taq buffer and $18 \mu \mathrm{l}$ of distilled 181 H2O as stated by Rourke \& Gilligan (2010) with slight modification.

182 The PCR reaction was carried out using a gradient Eppendorf Mastercycler based on the 183 following thermal adjusted protocol: 2 min of $95^{\circ} \mathrm{C}$ initial denaturation step; 35 cycles of $95{ }^{\circ} \mathrm{C}$ 184 denaturation step for $30 \mathrm{~s}$, a $55^{\circ} \mathrm{C}$ annealing temperature for $45 \mathrm{~s}$ and a $72^{\circ} \mathrm{C}$ extension period of $1851 \mathrm{~min}$; followed by a $72{ }^{\circ} \mathrm{C}$ final extension (elongation) step for $10 \mathrm{~min}$ and a routine $4{ }^{\circ} \mathrm{C}$ final 186 hold (Rourke et al., 2010; Rourke \& Gilligan, 2010). Afterwards, PCR amplification products 187 were visualized using a 4.0\% MetaPhor agarose gel containing $5 \mu$ l GelRed staining solution. 188 Subsequently, gel images were subjected to microsatellite screening and approximately $15 \mu 1$ of 189 the florescent label products were packed and sent to First Base laboratories (private institution) 190 for fragments analysis.

192 Genetic Analysis of Microsatellite markers

193 In order to verify any null alleles and scoring error, MICROCHECKER 2.2.3 (Van Oosterhout et 194 al., 2004) were applied using diploid data obtained from CONVERT software (Glaubitz, 2004). 195 GENEPOP 4.2 (Rousset, 2008) was employed in order to evaluate the conformity to the "Hardy- 
196 Weinberg expectations" (HWE) with 10000 permutations for test of exact probability. Observed

197 heterozygosity (HO) was estimated using GENALEX 6.5 (Peakall \& Smouse, 2012).

198 Successively, FSTAT 2.9.3.2 (Goudet, 1995) was applied to calculate the expected

199 heterozygosity (HE), with 15000 permutation and MolKin 3.0 (Gutiérrez et al., 2005) to validate

200 the genetic analysis among genetic dataset using Polymorphism Information Content (PIC).

201 Afterwards, ARLEQUIN 3.0 (Excoffier et al., 2005) were used to analyze the genetic

202 configuration, hierarchical molecular analysis (AMOVA) and pairwise $F_{S T}$ estimations among

203 all five involved populations, using reflection of 95\% significance level and 10000 permutations.

204 Assignment of each individual to their genetic groups $(K)$ employing admixture model and its

205 associated frequency of allelic data was carried out using the STRUCTURE program 2.1

206 (Pritchard et al., 2000). Next, GENECLASS2 2.0 (Piry et al., 2004) was implemented to conduct

207 assignment of individuals into the most plausible inheritance group. Finally, probability of

208 current bottleneck was tested using BOTTLENECK software 1.2.02 (Piry et al., 1999).

\section{$211 \quad$ RESULTS}

212 Phylogenetic and Population Analysis inferred from Mitochondrial DNA

214 Among overall number of 130 studied specimens using one COI gene, a full mass of 118 reliable 215 sequences (approximately 91\%) were identified. Once the sequencing was completed, the 216 C_Fish1 accordingly confirmed as suitable primer set amplifying in P.canius and P.lineatus 217 DNA samples. Nevertheless, in some cases there were some uncertain base calls, there was no 218 observation of any stop codons nor any instances of insertion or deletion in sequences. 219 Deficiency of structural stop codon more likely supposed to be associated with every amplified 220 mitochondrial sequences, and all that, alongside with the read length of amplified sequences 221 implies that nuclear sequences initiated from vertebrate mitochondrial DNA are not sequenced. 222 Such occasions are based on the fact that nuclear sequences have typically read lengths less than 223 600-bp (Zhang \& Hewitt, 1996). Therefore, the selected COI gene alone was considered for 224 phylogenetic and population structure analysis of P.canius and P.lineatus in advance. 
226 Preliminary evaluation of verified sequences was mainly generated 20 haplotypes in five

227 populations of P.canius and 3 Haplotypes in one population of P.lineatus (Table.1). Based on the

228 presented data of obtained haplotypes, it can be evidently seen that in P.canius samples,

229 KR086940 was found as the most common haplotype in the entire populations from Malaysia,

230 however it was not found in the Negeri Sembilan and the Sabah populations. Moreover,

231 KR086939 was detected as the second common haplotype in P.canius populations. The

232 N.Sembilan and the Selangor populations had the most unique haplotypes, while the Johor

233 population had just two shared haplotypes each. In other words, the N.Sembilan and the Selangor

234 population possessed the highest number of identified haplotypes $(n=6)$, while the N.Sembilan 235 and the Sabah populations had five and four haplotypes respectively.

\begin{tabular}{|c|c|c|c|}
\hline Species & $\begin{array}{c}\text { BOLDSYSTEM } \\
\text { Index }\end{array}$ & $\begin{array}{c}\text { GenBank Accession } \\
\text { Number }\end{array}$ & Sampling Site \\
\hline \multirow[t]{3}{*}{ Plotosus lineatus } & NUPM017-14 & KP258659 & \multirow[t]{3}{*}{ Selangor } \\
\hline & NUPM016-14 & KP258657 & \\
\hline & NUPM015-14 & KP258658 & \\
\hline \multirow{23}{*}{ Plotosus canius } & NUPM001-14 & KP258648 & \multirow[t]{4}{*}{ Negeri Sembilan } \\
\hline & NUPM002-14 & KP258651 & \\
\hline & NUPM006-14 & KP258655 & \\
\hline & NUPM023-15 & KR086935 & \\
\hline & NUPM003-14 & KP258650 & \multirow[t]{4}{*}{ Sabah } \\
\hline & NUPM004-14 & KP258649 & \\
\hline & NUPM005-14 & KP258656 & \\
\hline & NUPM022-15 & KR086936 & \\
\hline & NUPM007-14 & KP258654 & \multirow[t]{5}{*}{ Selangor } \\
\hline & NUPM008-14 & KP258653 & \\
\hline & NUPM009-14 & KP258652 & \\
\hline & NUPM020-15 & KR086938 & \\
\hline & NUPM021-15 & KR086937 & \\
\hline & NUPM010-14 & KP221601 & \multirow[t]{5}{*}{ Sarawak } \\
\hline & NUPM011-14 & KP221602 & \\
\hline & NUPM012-14 & KP221603 & \\
\hline & NUPM013-14 & KP221604 & \\
\hline & NUPM014-14 & KP221605 & \\
\hline & \multirow{3}{*}{ NUPM018-15 } & \multirow{3}{*}{ KR086940 } & Selangor \\
\hline & & & Sarawak \\
\hline & & & Johor \\
\hline & \multirow[t]{2}{*}{ NUPM019-15 } & \multirow[t]{2}{*}{ KR086939 } & Johor \\
\hline & & & Negeri Sembilan \\
\hline
\end{tabular}


237 For the 655 available COI nucleotides, 509 sites (roughly $78 \%$ ) were detected as conserved 238 sites, $146(22 \%)$ as variable sites and $136(21 \%)$ identified as parsim-informative sites. The 239 average nucleotide composition in P.canius was $29 \%$ T, $27.6 \%$ C, $25.2 \%$, A, and $18.3 \%$ G, while 240 the average $\mathrm{C}+\mathrm{G}$ content of selected positions was calculated as $45.9 \%$, in P.lineatus though, 241 calculation was 28, 28.6, 25, 18.4 and 47\% respectively. Translation of all 23 haplotypes for 242 conserved $655 \mathrm{bp}$ fragment was produced 165 amino acids, which presented no signal of 243 pseudogene in their structure. However sample size noticeably varied ranging from 13 to 30 in 244 collected samples of P.lineatus and P.canius from five different districts in Malaysia, and 245 regarding to the fact that original sample sizes were moderate and some sequences were failed, 246 the actual sample collection is in the desired range recommended by Zhang et al. (2010). 247 Basically, in order to detect approximately 80\% genetic variation, a collection of 31.9 to 617.8 248 samples could be needed; although it is far from real laboratory and field work measures; hence 249 it is suggested that at least 10 sample might be desirably sufficient to accurately identify the 250 genetic variability in real phylogenetic studies (Zhang et al., 2010). An overview of most crucial 251 outcomes in polymorphism analysis (Table. 2) indicated that the number of variable sites are moderately fluctuating from 2 in P.lineatus to 54 in P.canius samples from Sarawak, While the 253 degree of nucleotide diversity was relatively low (0.00067-0.0391) and as its consequence, the 254 level of polymorphism and genetic variation in populations reasonably presented small portion. Besides, the degree of haplotypes diversity waved from 0.395 (Sabah) to 0.771 (Sarawak).

256 The Tamura-Nei pairwise distance matrix (Table. 3) indicated a comparatively high overall 257 interspecies pairwise divergence of $25.2 \%$, while the least interspecific distance was $0.2 \%$. The 258 Tamura-Nei intraspecific distance however, ranged from $0.2 \%$ to $9.7 \%$ between P.canius from 259 Sarawak and Selangor. Nevertheless, the majority of P.canius pairwise distances displayed low 260 levels of conspecific divergence roughly around $1 \%$. The greatest genetic differences was 261 observed between the Selangor and Sarawak (KR086937-KP221604) samples (9.7\%), which is 262 moderately reasonable due to their geographical distance. The next significantly high variances 263 was detected between the Sabah-Sarawak pair (KP258656-KP221604) and Negeri Sembilan264 Sarawak (KP258654-KP221604), although in later occasion, distance between Sarawak-Sabah 265 sites is extraordinarily closer than Sarawak-Negeri Sembilan. 


\begin{tabular}{|c|c|c|c|c|c|c|}
\hline Haplotype & & & canius & & & P.lineatus \\
\hline $\begin{array}{c}\text { GenBank Accession } \\
\text { Number }\end{array}$ & $\begin{array}{l}\text { Selangor } \\
n=20\end{array}$ & $\begin{array}{c}\text { Negeri } \\
\text { Sembilan } \\
\quad n=18\end{array}$ & $\begin{array}{l}\text { Johor } \\
n=15\end{array}$ & $\begin{array}{l}\text { Sabah } \\
n=30\end{array}$ & $\begin{array}{c}\text { Sarawak } \\
n=22\end{array}$ & $\begin{array}{c}\text { Selangor } \\
n=13\end{array}$ \\
\hline KP258659 & & & & & & 7.8 \\
\hline KP258657 & & & & & & 15.3 \\
\hline KP258658 & & & & & & 76.9 \\
\hline KP258648 & & 5.6 & & & & \\
\hline KP258651 & & 16.6 & & & & \\
\hline KP258655 & & 11.1 & & & & \\
\hline KR086935 & & 5.6 & & & & \\
\hline KP258650 & & & & 3.3 & & \\
\hline KP258649 & & & & 3.3 & & \\
\hline KP258656 & & & & 76.6 & & \\
\hline KR086936 & & & & 16.8 & & \\
\hline KP258654 & 5 & & & & & \\
\hline KP258653 & 10 & & & & & \\
\hline KP258652 & 5 & & & & & \\
\hline KR086938 & 5 & & & & & \\
\hline KR086937 & 10 & & & & & \\
\hline KP221601 & & & & & 4.5 & \\
\hline KP221602 & & & & & 31.8 & \\
\hline KP221603 & & & & & 13.6 & \\
\hline KP221604 & & & & & 4.5 & \\
\hline KP221605 & & & & & 9 & \\
\hline KR086940 & 65 & & 60 & & 36.6 & \\
\hline KR086939 & & 61.1 & 40 & & & \\
\hline $\begin{array}{l}\text { Nucleotide Diversity } \\
\text { (Pi JC) }\end{array}$ & 0.00457 & 0.00184 & 0.00306 & 0.00134 & 0.0391 & 0.00067 \\
\hline Number of Haplotypes & 6 & 5 & 2 & 4 & 6 & 3 \\
\hline Haplotype Diversity (Hd) & 0.642 & 0.614 & 0.667 & 0.395 & 0.771 & 0.410 \\
\hline $\begin{array}{c}\text { Number of Polymorphic } \\
\text { site }\end{array}$ & 14 & 5 & 3 & 4 & 57 & 2 \\
\hline
\end{tabular}

267 *Haplotype frequencies in each population are presented as percentage.

268 Table. 2) Summary of 23 observed mitochondrial DNA haplotypes and their distribution, nucleotide diversity, number of haplotypes, haplotype diversity and number of polymorphic sites. 


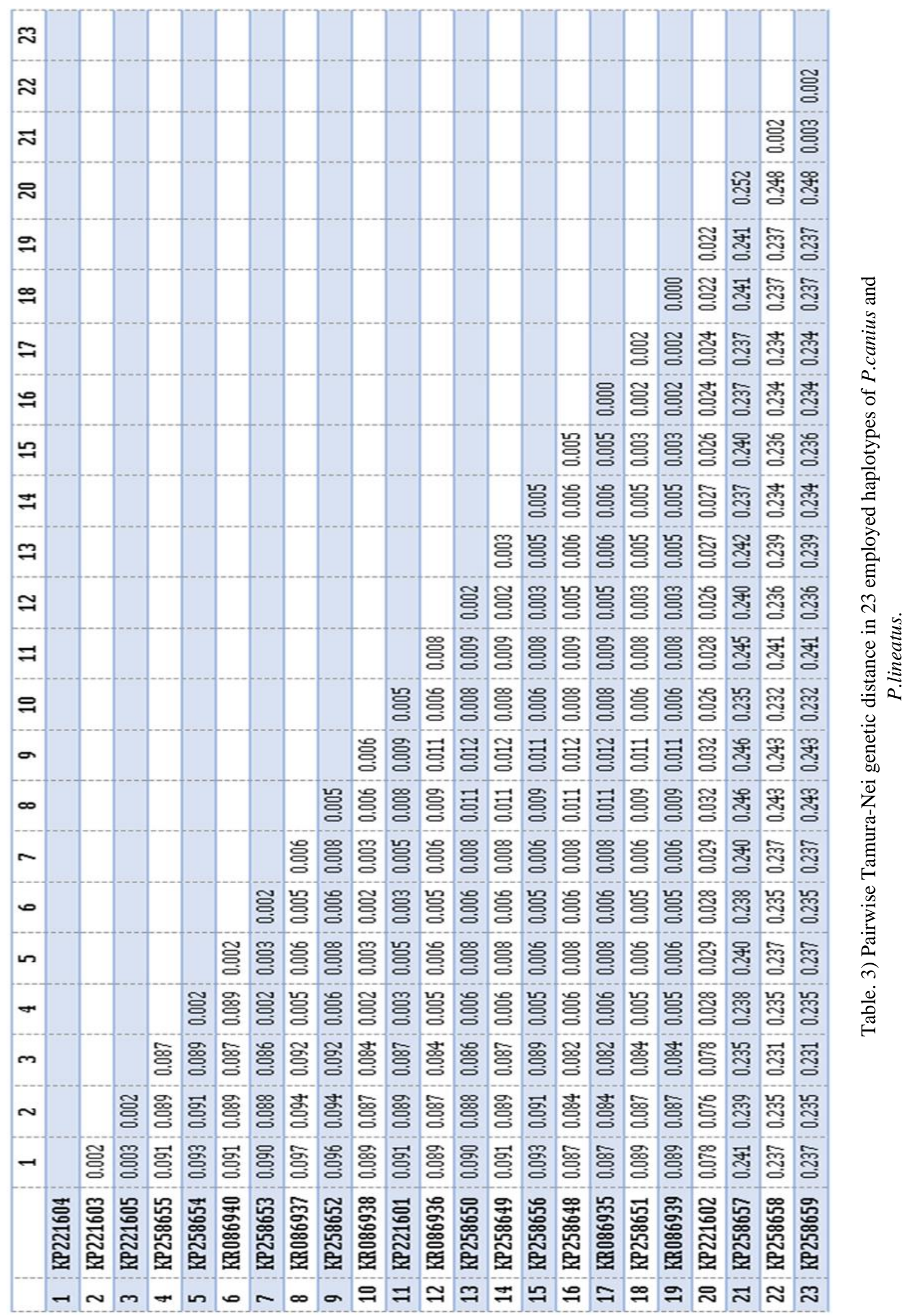


271 Phylogenetic analysis using the 23 haplotypes of the genus Plotosus and one haplotype of 272 C.gariepinus showed monophyletic status between P.canius and P.lineatus via the Neighbour273 Joining method (Figure. 2). As stated, the three haplotypes from Sarawak population formed a 274 basal clade for P.canius using Neighbour-Joining algorithm. Moreover, constructed topology 275 precisely proved the pairwise genetic distances of shared haplotypes, highlighting that 276 KR086940 (SGR, SWK, JHR) have the lowest distance to KP258654 (SGR) and highest to 277 KP221604 (SWK), while KR086939 (JHR, NSN) have the greatest divergence from KP221604 278 (SWK) and smallest amount from KP258648 (NSN), as their subdivision clades illustrated.

282

283

284 285

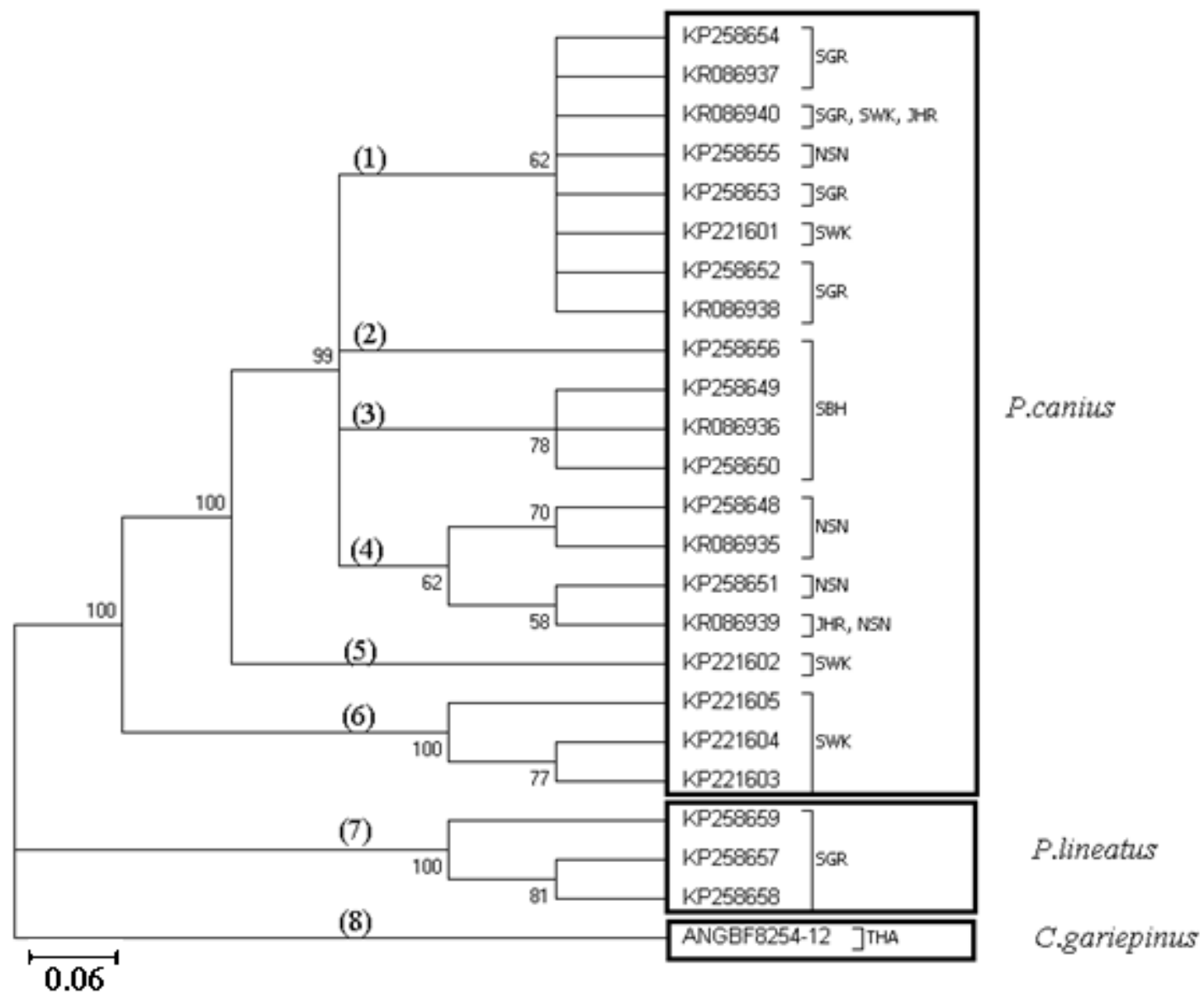

Figure. 2) Summary of Neighbour-Joining relationship in 24 employed sequences of P.canius, P.lineatus and C.gariepinus (clades have been indicated by bold numbers in round brackets).

Similarly, application of Maximum Likelihood algorithm (Figure. 3) have been subsequently confirmed the calculation of pairwise genetic distances among sequences of P.canius and P.lineatus with exception of some negligible changes in topology of clades and branches. 


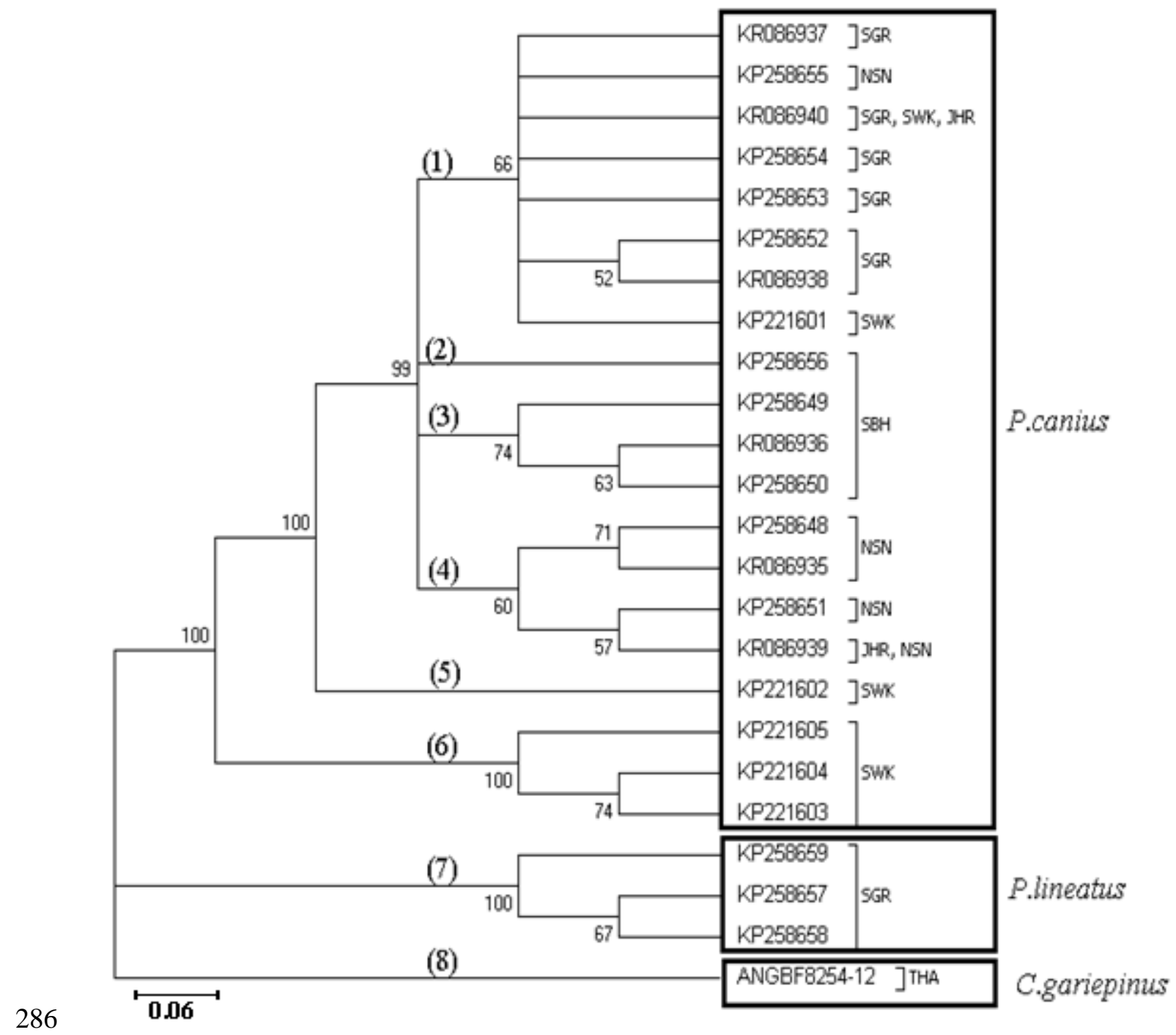

290 The Minimum Spanning Network (MSN) of 20 haplotypes of P.canius (Figure. 4) in Malaysia 291 presented more haplotype variability in Sarawak and Negeri Sembilan populations with six and 292 five haplotypes respectively. Indeed, the Sarawak and Negeri Sembilan sequences illustrated a 293 fairly high diversity, while the two haplotypes of Johor possessed the lowest variability. 294 However, the phylogram revealed two relatively irrefutable geographical clades (Sarawak and 295 Negeri Sembilan), occurrence of mix haplotypes with other clades indicating that no accurate 296 geographical genetic structure have been certainly detected in studied populations of P.canius. 
297 Analysis of potential geographical clades have been similarly suggested that all populations are

298 moderately mixed except in Sarawak and Negeri Sembilan. Although there are some possible 299 clades, it was not precisely feasible to clustering the population based on their geographical 300 divisions due to existence of exclusively one connecting mutational steps for most sequences. 301 Hence, analysis was not capable of showing precise separation of geographical clades.

302

303

304

305

306

307

308

309

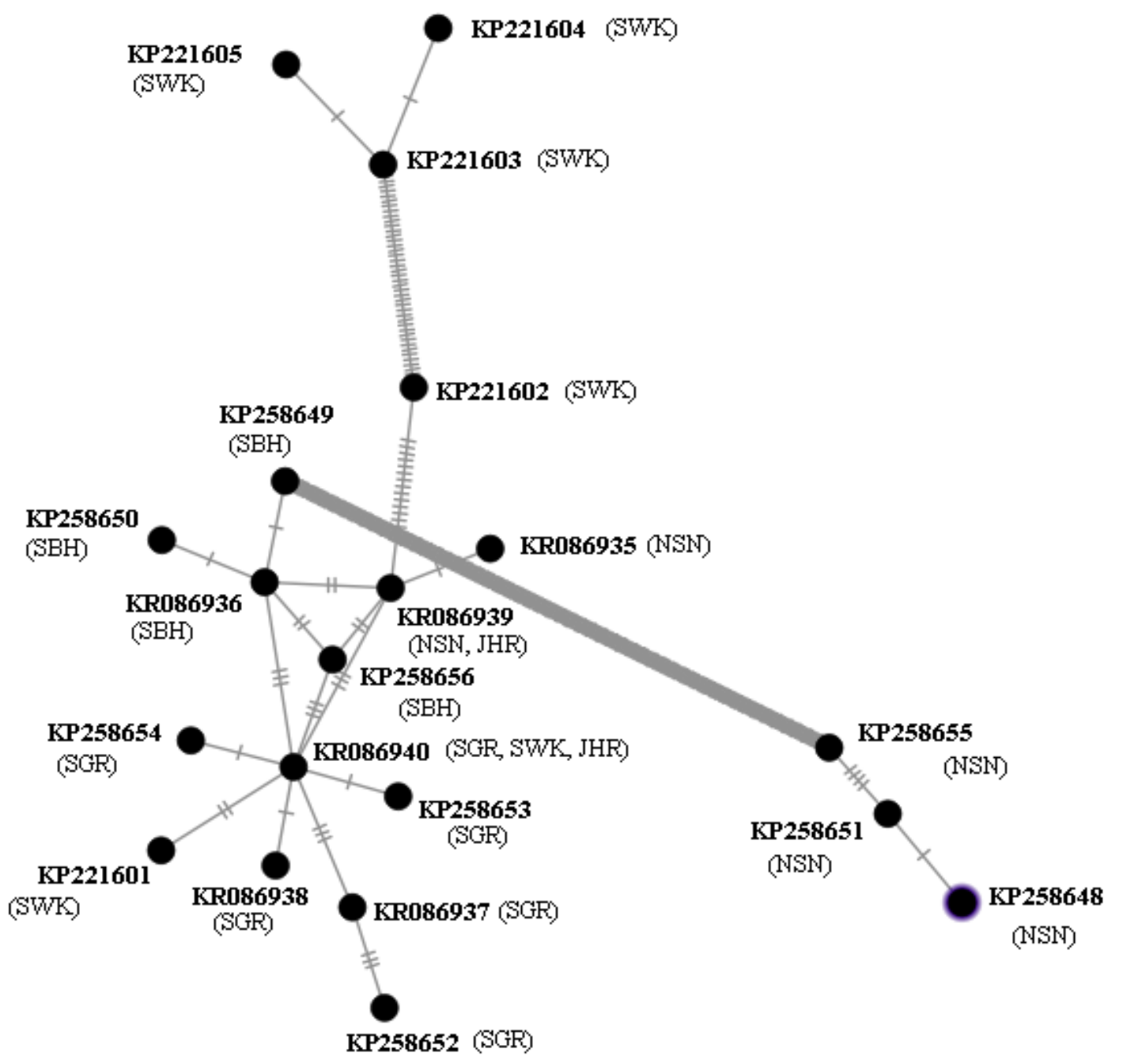

Figure. 4) Minimum Spanning Network (MSN) of 20 haplotypes of P.canius.

Analysis of population differentiation inferred from pairwise distance of $F_{S T}$ and Chi-square among studied populations of P.canius is displayed in Table. 4. Significant genetic variations were detected in all assessments within P.canius sequences and two considered species of eel-tail catfishes $(p<0.001)$. However, there were significant distance diversity in genetic variations of 
310 almost entire evaluations among populations of Malaysia especially between the Sabah and the

311 Negeri Sembilan populations. As expected, the most diversity were identified between P.canius

312 populations from the Negeri Sembilan and the Sabah with the rate of 0.62504, which basically

313 means they are nearly genetically divided due to their distance and subsequent decrease in gene

314 flow. However, the lowest genetic distance was detected between Selangor cluster and the Johor

315 clade by the $F_{S T}$ values of 0.05417 . Hence, it was considered that maximum sharing of genetic

316 material occurred between Johor and Selangor Populations, while the minimum genetic

317 similarity identified among Sabah and Negeri Sembilan sequences.

\begin{tabular}{|c|c|c|c|c|c|}
\hline & $\begin{array}{c}\text { P.canius } \\
\text { SBH }\end{array}$ & $\begin{array}{c}\text { P.canius } \\
\text { JHR }\end{array}$ & $\begin{array}{c}\text { P.canius } \\
\text { SGR }\end{array}$ & $\begin{array}{c}\text { P.canius } \\
\text { NSN }\end{array}$ & $\begin{array}{c}\text { P.canius } \\
\text { SWK }\end{array}$ \\
\hline $\begin{array}{c}\text { P.canius } \\
\text { SBH }\end{array}$ & 0.00000 & & & & \\
\hline $\begin{array}{c}\text { P.canius } \\
\text { JHR }\end{array}$ & 0.60156 & 0.00000 & & & \\
\hline $\begin{array}{c}\text { P.canius } \\
\text { SGR }\end{array}$ & 0.43390 & 0.05417 & 0.00000 & & \\
\hline $\begin{array}{c}\text { P.canius } \\
\text { NSN }\end{array}$ & 0.62504 & 0.44097 & 0.09806 & 0.00000 & \\
\hline $\begin{array}{c}\text { P.canius } \\
\text { SWK }\end{array}$ & 0.41533 & 0.27777 & 0.29359 & 0.31333 & 0.00000 \\
\hline
\end{tabular}

322 Hierarchical statistics of AMOVA (Table. 5) was clearly suggested that roughly $36 \%$ of experimental deviations were inter-population variations, while within population variations were merely responsible for approximately $64 \%$ of overall differentiation.

\begin{tabular}{|c|c|c|c|c|}
\hline $\begin{array}{c}\text { Source of } \\
\text { Variation }\end{array}$ & $\begin{array}{c}\text { Degree of } \\
\text { Freedom }\end{array}$ & Sum of Squares & $\begin{array}{c}\text { Variance } \\
\text { Components }\end{array}$ & $\begin{array}{c}\text { Percentage of } \\
\text { Variation }\end{array}$ \\
\hline $\begin{array}{c}\text { Among } \\
\text { Populations }\end{array}$ & 4 & 77.873 & 3.09472 & 35.55 \\
\hline $\begin{array}{c}\text { Between } \\
\text { Populations }\end{array}$ & 18 & 100.969 & 5.60941 & 64.45 \\
\hline
\end{tabular}

Table. 5) Hierarchical analysis of molecular variance (AMOVA) in P.canius. 

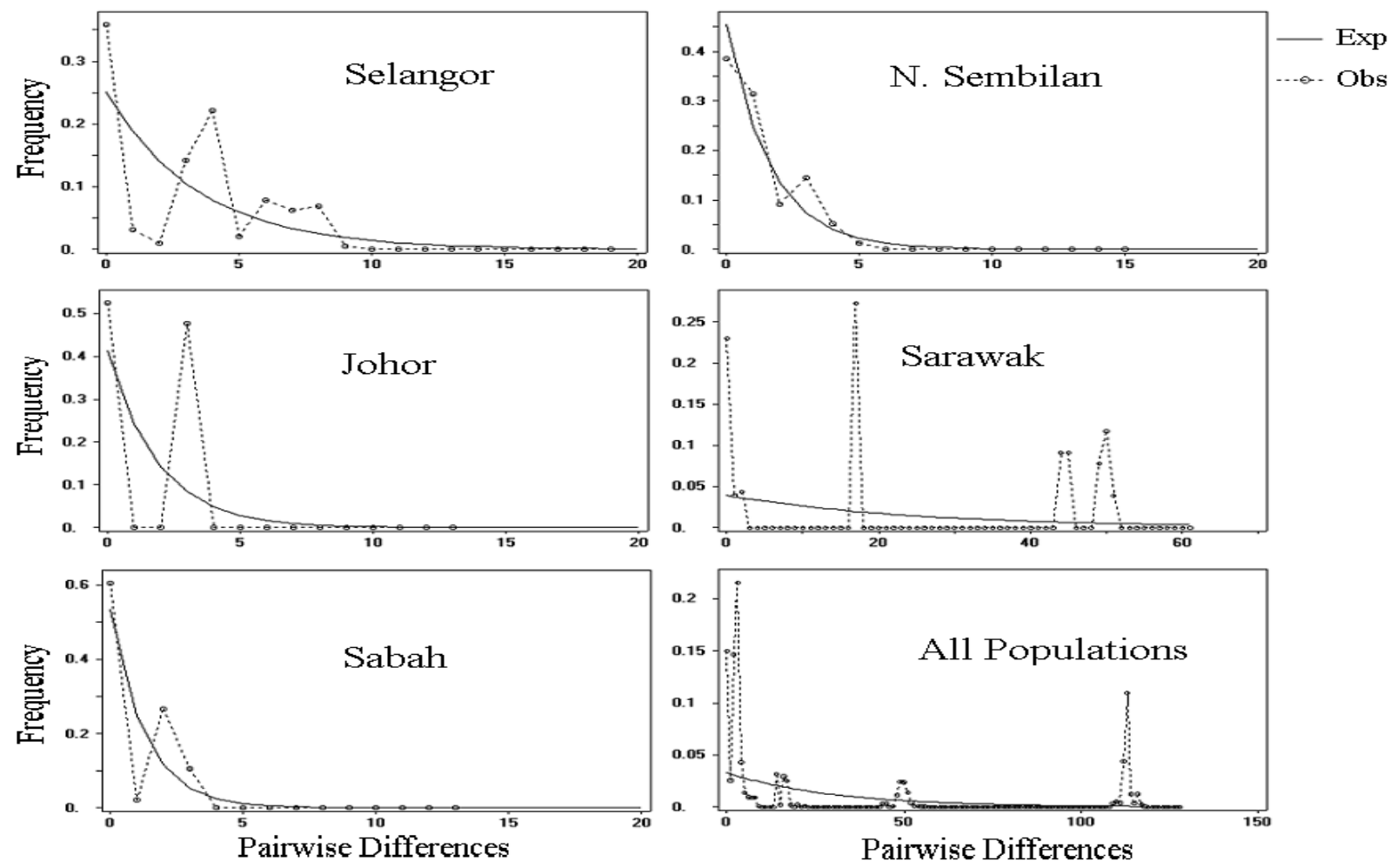

326 327

336

Figure. 5) Mismatch distribution of P.canius for different geographical regions and whole population.

The illustration of mismatch distribution (Figure. 5) have shown multimodal pattern for P.canius populations in Malaysia. Moreover, Tajima's $D$ test was negative for Selangor, Sabah and N.Sembilan populations, but not significant (Table. 6). Besides, the Fu's test showed negative signal for Selangor population, which wasn't similarly significant. These statistics suggest that populations of P.canius didn't possibly experience demographic expansion for a long period of time in Malaysia. However, comparison of $\theta_{1}$ and $\theta_{o}$ parameters for all populations indicates a relatively slow growth rate in female populations except in Sabah.

Species

Tajima's $D$

Fu's Fs

Mismatch distribution

\begin{tabular}{c|ccccccc} 
& $D$ & $P$ & $F s$ & $P$ & $\tau(95 \% \mathrm{CI})$ & $\theta_{0}$ & $\theta_{1}$ \\
Selangor & -0.89 & 0.20 & -0.01 & 0.53 & 10.98 & 1.64 & 3.44 \\
N. Sembilan & -0.84 & 0.23 & 0.72 & 0.61 & 4.18 & 0.334 & 0.62 \\
Johor & 1.63 & 0.96 & 3.63 & 0.94 & 26.17 & 0.99 & 1.51 \\
Sabah & -0.35 & 0.42 & 0.08 & 0.49 & 0.74 & 0.001 & 99783 \\
Sarawak & 2.24 & 0.99 & 15.14 & 1.00 & 58.39 & 26.44 & 53.03 \\
All Populations & 1.42 & 0.38 & 6.08 & 0.33 & 22.39 & 8.74 & 51632
\end{tabular}

Table. 6) Tajima's $D$ and Fu's $F s$, corresponding $P$-value, and mismatch distribution parameter estimates

(significance level: $\mathrm{P}<0.01$ ). 
Population Genetic results inferred from Genotyping analysis

Fragment analysis were estimated DNA band sizes in P.canius that are illustrated alongside with size range in original species (Tandanus tandanus), the sequence of each primers and associate annealing temperatures in Table. 7.

\begin{tabular}{|c|c|c|c|c|}
\hline Primer & Sequence & $\begin{array}{c}\text { Size } \\
\text { T.tandanus }\end{array}$ & $\begin{array}{l}\text { Size } \\
\text { P.canius }\end{array}$ & $\begin{array}{l}\text { Annealing } \\
\text { Temperature }\end{array}$ \\
\hline Tan 1-2 & $\begin{array}{l}\text { F: 5'CCGACTGTCAGTGAAAAGGAG3' } \\
\text { R: 5'AGGGTCTGGGAGTGAATGAG3' }\end{array}$ & $216-244$ & $349-385$ & $55^{\circ} \mathrm{C}$ \\
\hline Tan 1-7 & $\begin{array}{c}\text { F: 5'TGTATGGAGCTACTAACAAAACAGG3' } \\
\text { R: 5'TACTCCAGCCCTGAAGGTG3' }\end{array}$ & $181-227$ & $114-125$ & $55^{\circ} \mathrm{C}$ \\
\hline Tan 1-10 & $\begin{array}{l}\text { F: 5'CCTGATTTCTCTCCCAAGG3' } \\
\text { R: 5'AGAAAGGTGGTGCATGTGTG3' }\end{array}$ & 298-310 & $91-97$ & $55^{\circ} \mathrm{C}$ \\
\hline Tan 3-27 & $\begin{array}{l}\text { F: 5'TGTGGAAGGTTGGGGTTATG3' } \\
\text { R: 5'CGTGATCATGCAAACAGATG3' }\end{array}$ & $215-269$ & $167-168$ & $55^{\circ} \mathrm{C}$ \\
\hline Tan 3-28 & 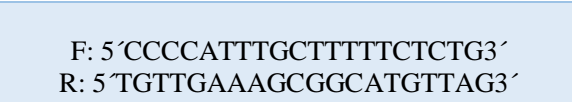 & 289-301 & $280-299$ & $55^{\circ} \mathrm{C}$ \\
\hline
\end{tabular}

Table. 7) Five engaged primer sets and their associated size and temperature in T.tandanus and P.canius.

Genotyping results did not found any signal of null allele nor large allele failure, hence nor scoring inaccuracies due to stuttering. All the five microsatellites loci showed accurate and successful amplification in all populations, although heterozygous alleles were not found in all populations. One microsatellite loci (Tan3-27), was evidently monomorphic in all populations while Tan 1-2, Tan 1-10, Tan 1-7 and Tan 3-28 were polymorphic in at least one population. After implementing the sequential Bonferroni adjustment (Rice, 1989), only four out of the 50 (8\%) loci pairs were significant for linkage disequilibrium $(P<0.05)$. Thus, all the five microsatellites loci were considered useful for genetic applications based on the absence of consistent linkage disequilibrium in locus pairs among the studied populations.

Furthermore, after Bonferroni adjustment, nine out of the $25(36 \%)$ microsatellite loci still showed deviation from Hardy-Weinberg Equilibrium (HWE), which might be owing to heterozygote deficiency effects (Table. 8). Heterozygote deficiency could be caused by population structuring, null alleles or inbreeding (Brook et al., 2002). 


\begin{tabular}{|c|c|c|c|c|c|c|}
\hline \multirow[t]{2}{*}{ Locus } & \multirow[t]{2}{*}{ N.Sembilan } & \multirow[t]{2}{*}{ Sabah } & \multirow[t]{2}{*}{ Selangor } & \multirow[t]{2}{*}{ Sarawak } & \multirow[t]{2}{*}{ Johor } & \multirow{2}{*}{$\frac{\text { Total* }}{\text { Mean }}$} \\
\hline & & & & & & \\
\hline$N$ & 30 & 30 & 20 & 22 & 15 & 117 \\
\hline \multicolumn{7}{|l|}{ Tan 1-2 } \\
\hline$N_{a}$ & 1 & 2 & 1 & 1 & 2 & 4 \\
\hline $\mathbf{A r}$ & 1.000 & 2.000 & 1.000 & 1.000 & 2.000 & 3.714 \\
\hline$H_{O}$ & 0.0000 & 0.0000 & 0.0000 & 0.0000 & 0.6000 & 0.0769 \\
\hline $\boldsymbol{H}_{e}$ & 0.0000 & 0.4994 & 0.0000 & 0.0000 & 0.4345 & 0.5974 \\
\hline Fis & - & 0.000 & - & - & -0.400 & \\
\hline HW & - & 1.0000 & - & - & 0.1791 & \\
\hline \multicolumn{7}{|l|}{ Tan 1-7 } \\
\hline$N_{a}$ & 2 & 2 & 3 & 2 & 1 & 6 \\
\hline $\mathbf{A r}$ & 2.000 & 2.000 & 3.000 & 2.000 & 1.000 & 5.844 \\
\hline$H_{0}$ & 1.000 & 0.0000 & 0.6000 & 0.0000 & 0.0000 & 0.3590 \\
\hline $\boldsymbol{H}_{\boldsymbol{e}}$ & 0.5085 & 0.4994 & 0.6769 & 0.4947 & 0.0000 & 0.7727 \\
\hline Fis & -1.000 & 1.000 & 0.116 & 1.000 & - & \\
\hline HW & 0.0000 & 1.0000 & 0.5856 & 1.0000 & - & \\
\hline \multicolumn{7}{|c|}{ Tan 1-10 } \\
\hline$N_{a}$ & 1 & 1 & 1 & 1 & 2 & 3 \\
\hline Ar & 1.000 & 1.000 & 1.000 & 1.000 & 2.000 & 2.564 \\
\hline$H_{O}$ & 0.0000 & 0.0000 & 0.0000 & 0.0000 & 0.4000 & 0.0513 \\
\hline $\boldsymbol{H}_{e}$ & 0.0000 & 0.0000 & 0.0000 & 0.0000 & 0.3310 & 0.3472 \\
\hline Fis & - & - & - & - & -0.217 & \\
\hline HW & - & - & - & - & 0.5395 & \\
\hline \multicolumn{7}{|c|}{ Tan 3-27 } \\
\hline$N_{a}$ & 1 & 1 & 1 & 1 & 1 & 2 \\
\hline $\mathbf{A r}$ & 1.000 & 1.000 & 1.000 & 1.000 & 1.000 & 1.988 \\
\hline$H_{0}$ & 0.0000 & 0.0000 & 0.0000 & 0.0000 & 0.0000 & 0.0000 \\
\hline $\boldsymbol{H}_{e}$ & 0.0000 & 0.0000 & 0.0000 & 0.0000 & 0.0000 & 0.2242 \\
\hline Fis & - & - & - & - & - & \\
\hline HW & - & - & - & - & - & \\
\hline \multicolumn{7}{|c|}{ Tan 3-28 } \\
\hline$N_{a}$ & 3 & 2 & 3 & 2 & 1 & 8 \\
\hline Ar & 3.000 & 2.000 & 3.000 & 2.000 & 1.000 & 7.592 \\
\hline$H_{O}$ & 0.4667 & 1.0000 & 0.3000 & 0.0000 & 0.0000 & 0.4274 \\
\hline $\boldsymbol{H}_{e}$ & 0.6169 & 0.5885 & 0.4769 & 0.4947 & 0.0000 & 0.8393 \\
\hline Fis & 0.247 & -1.000 & 0.377 & 1.000 & - & \\
\hline HW & 0.5862 & 0.0000 & 0.5771 & 1.0000 & - & \\
\hline
\end{tabular}

Table. 8) Genetic variation at 5 microsatellite as of five populations of P.canius in Malaysia: sample size $(N)$, Number of alleles $\left(N_{a}\right)$, allele richness $(A r)$, observed heterozygosity $\left(H_{0}\right)$, expected heterozygosity $\left(H_{e}\right)$, inbreeding coefficient (Fis) ( $\mathrm{p}<0.05$ symbolic accustomed nominal level (5\%) 0.000042, and HardyWeinberg expectation (disequilibrium) (HW).

Data from Table. 8 showed that six out of nine deviations were related to Tan1-7 and Tan 3-28 among all the five P.canius populations. The fact that the two loci did not show any signal of deviation from HWE in three populations may imply the probability that the estimated deviations could have been originated from either the occurrence of uncertain structure or inbreeding among these three population divisions (Pritchard et al., 2000). Fairly high level of consistency 
372 was detected toward inclusion or exclusion of Tan1-7 and Tan 3-28, accordingly these loci have

373 been retained for further analysis. Fis $(\mathrm{P}<0.05)$ estimations have been considerably diverse

374 from zero, except in locus Tan 1-2 from Sabah. This alongside with substantial departure from

375 HWE indicates the damaging effect of heterozygote deficiency within associated populations.

376 However, the positive calculated estimations could be translated as decrease in heterozygous

377 levels among offspring in population, mostly owning to non-random mating and its subsequent

378 inbreeding. On the other hand, negative Fis estimates might be indication of increasing in

379 heterozygosity level, which could usually occur as a result of random mating system, hence

380 genes should be probably more different (Pritchard et al., 2000).

381 Analysis of population genetic inferred from molecular coancestry information (Table. 9)

382 revealed that Polymorphism Information Content (PIC) of the applied microsatellites varied from

38319.86 to 73.99. However, loci with numerous allele numbers and a PIC value of 1 are considered

384 as highly polymorphic and thus most desirable, lowest rates are also slightly informative (if and

385 only if PIC > 0) (Botstein et al., 1980). Besides, the arithmetic values of heterozygosity

$386(0.2235-0.8357)$ confirmed the consistent application of all the 5 microsatellite loci in population

387 genetic study of P.canius in Malaysia.

\begin{tabular}{|c|c|c|c|c|}
\hline Microsatellite & $\mathbf{N}_{\mathbf{a}}$ & Heterozigosity & $\operatorname{PIC}(\%)$ & Effective Allele NO. \\
\hline Tan 1-2 & 4 & 0.5949 & 54.12 & 2.47 \\
\hline Tan 1-7 & 6 & 0.7694 & 73.99 & 4.34 \\
\hline Tan 1-10 & 3 & 0.3457 & 30.11 & 1.53 \\
\hline Tan 3-27 & 2 & 0.2235 & 19.86 & 1.29 \\
\hline Tan 3-28 & 8 & 0.8357 & 81.71 & 6.09 \\
\hline
\end{tabular}

Polymorphism Information Content (PIC).

Hierarchical results of microsatellites showed that approximately 64 per cent of experimental variations were originated from inter - population variations, while within individuals variations were only accountable for roughly 28.5 per cent of overall differentiation (Table. 10). 


\begin{tabular}{|c|c|c|c|}
\hline Source of variation & Sum of squares & $\begin{array}{c}\text { Variance } \\
\text { components }\end{array}$ & Variation \% \\
\hline $\begin{array}{c}\text { Among } \\
\text { Populations }\end{array}$ & 191.456 & 1.02366 & 63.77361 \\
\hline $\begin{array}{l}\text { Among individuals } \\
\text { within populations }\end{array}$ & 79.039 & 0.12422 & 7.73898 \\
\hline $\begin{array}{c}\text { Within } \\
\text { Individuals }\end{array}$ & 53.500 & 0.45726 & 28.48741 \\
\hline
\end{tabular}

399

400

401

$402 \quad F_{S T}$ plot estimations of all involved microsatellites noticeably illustrated that all pairwise

Table. 10) Hierarchical analysis of molecular variance (AMOVA) in P.canius. calculations presented a fairly high differentiations among populations ranging from 0.29711 between populations of Selangor and Negeri Sembilan to 0.80500 between populations of Sarawak and Johor (Table. 11). The current microsatellite experiment showed that the highest genetic differentiation was between the Johor population and the other populations from Peninsular Malaysia and Borneo. Indeed, the Johor population showed strong deviation from other collected populations, while displayed relatively low intra-population genetic variation (Table. 11), suggesting that the Johor population was less connected to the others during a sizeable period of its evolutionary phase. Likewise, the Sarawak population in the Southwest region of the South China Sea had high $F_{S T}$ values between other populations, signifying the restricted gene flow between the Sarawak population and the other populations. The differentiation level among populations of Negeri Sembilan and Selangor $\left(F_{S T}=0.29711, \mathrm{P}<\right.$ 0.05) showed relatively lower values, even in comparison with their neighbouring populations, theoretically demonstrating the populations that endured inbreeding or genetic drift since their isolation from other populations. Similarly, the Negeri Sembilan and Sabah $\left(F_{S T}=0.39244, \mathrm{P}<\right.$ 0.05 ) populations also showed small but significant variances in relation to their close neighbour populations.

\begin{tabular}{|l|c|c|c|c|c|c|}
\hline & & N.Sembilan & Sabah & Selangor & Sarawak & Johor \\
\hline $\mathbf{1}$ & N.Sembilan & 0.00000 & & & & \\
\hline $\mathbf{2}$ & Sabah & 0.39244 & 0.00000 & & & \\
\hline $\mathbf{3}$ & Selangor & 0.29711 & 0.41039 & 0.00000 & & \\
\hline $\mathbf{4}$ & Sarawak & 0.71934 & 0.68086 & 0.72437 & 0.00000 & \\
\hline $\mathbf{5}$ & Johor & 0.73211 & 0.68561 & 0.74834 & 0.80500 & 0.00000 \\
\hline
\end{tabular}

Table. 11) Pairwise $F_{S T}$ estimations through P.canius populations generated from five microsatellites loci and inclusion of five populations. All calculations were fairly significant $(P<0.05)$ using 10000 permutations. 
422 Levels of genetic variations seem to be widely fluctuated between P.canius populations owning 423 to $H_{e}$ and $A r$ oscillation on which $H_{e}$ extending from 0.0000 to 0.6769 (Selangor) and $A r$ varied 424 from 1 to 3 (Negeri Sembilan and Selangor). Obviously, two significant clusters could be seen 425 among established populations of P.canius in this study, one cluster with low allelic richness and $426 H_{e}$ estimations (Johor samples using locus Tan 1-2 and locus Tan 1-10), and another cluster with 427 relatively acceptable $H_{e}$ and allelic richness (the other four populations using locus Tan 3-28 and 428 locus Tan 1-7). However, the genetic variation in the current study was highly reliant on 429 microsatellites and their sequences as the engaged loci did not specifically develop for P.canius. 430 Moreover, allelic frequencies among virtually each combination of population pairs showed 431 highly significant differentiation $\left(F_{S T}<0.05\right)$ (Table. 11), implying that gene flow might be 432 highly restricted among studied populations.

433 Sampled populations of P.canius were basically distributed into five minor clusters using 434 Bayesian analysis. Consequently, the initial highest membership value (q) of the studied 435 populations including Negeri Sembilan, Sabah, Selangor, Sarawak, Johor was estimated as $4360.941,0.983,0.968,0.988$, and 0.986 respectively (Table. 12). The application of STRUCTURE 437 program subsequently illustrated 4 major $K$ (isolated clusters) (Figure. 6). Regarding the fact that 438 assessing the expected value of $K$ might not be straightforward (Evanno et al., 2005), Bayesian 439 structure analysis of the current study revealed the highest probability of $K$ for P.canius in $K=2$. 440 The four estimated clusters were included Cluster 1: Johor, Cluster 2: N.Sembilan and Selangor, 441 Cluster 3: Sabah, and Cluster 4: Sarawak (Figure. 7).

\begin{tabular}{|c|c|c|c|c|c|}
\hline \multirow{2}{*}{ Populations } & \multicolumn{5}{|c}{ Cluster Membership } \\
\cline { 2 - 6 } & $\mathbf{1}$ & $\mathbf{2}$ & $\mathbf{3}$ & $\mathbf{4}$ & $\mathbf{5}$ \\
\hline N.Sembilan & 0.005 & 0.041 & 0.941 & 0.010 & 0.004 \\
\hline Sabah & 0.005 & 0.004 & 0.005 & 0.983 & 0.003 \\
\hline Selangor & 0.005 & 0.968 & 0.019 & 0.005 & 0.004 \\
\hline Sarawak & 0.003 & 0.003 & 0.003 & 0.003 & 0.988 \\
\hline Johor & 0.985 & 0.004 & 0.004 & 0.004 & 0.003 \\
\hline
\end{tabular}


447

448

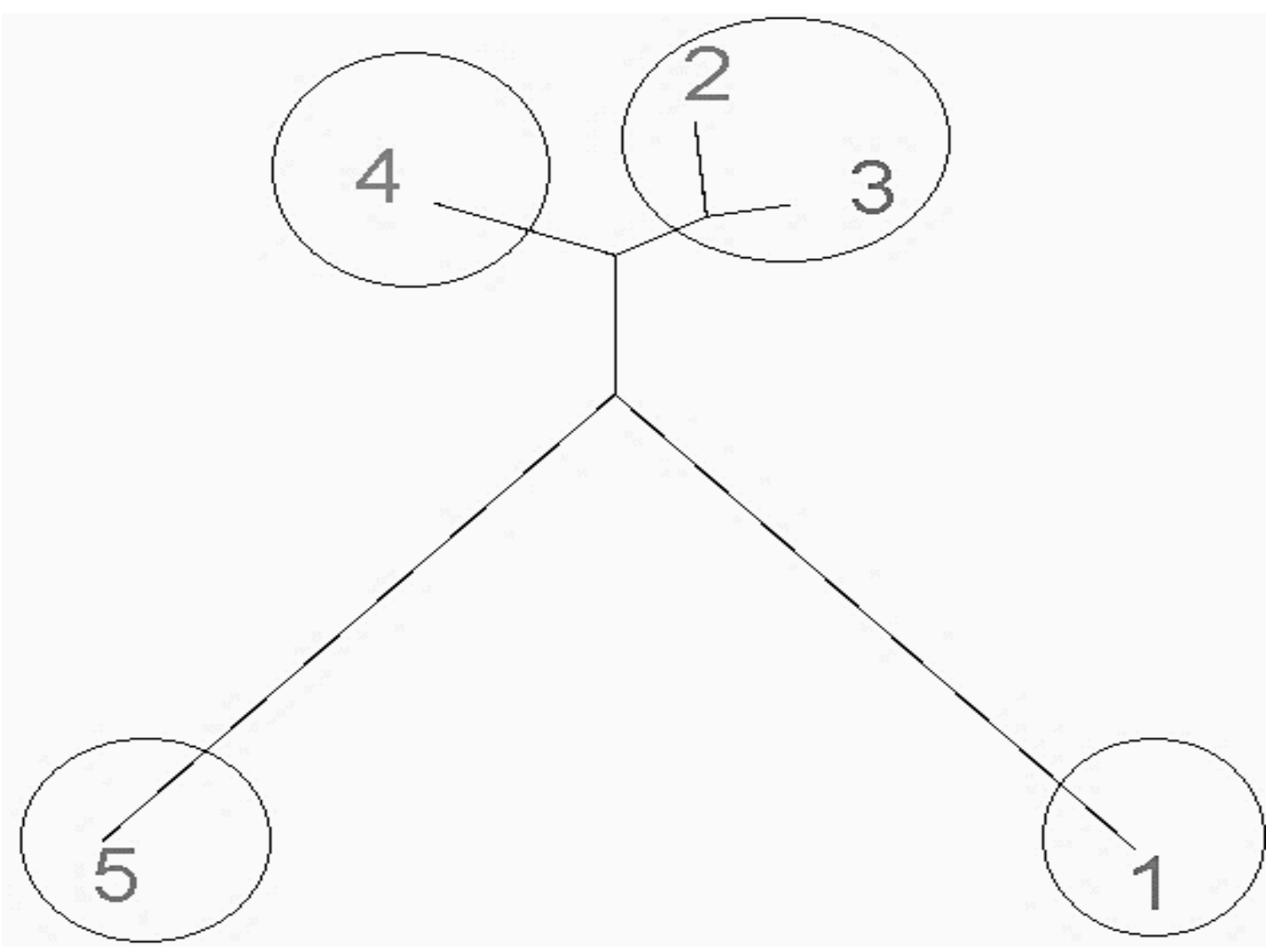

Figure. 6) Tree plot scheme of five engaged populations of P.canius.

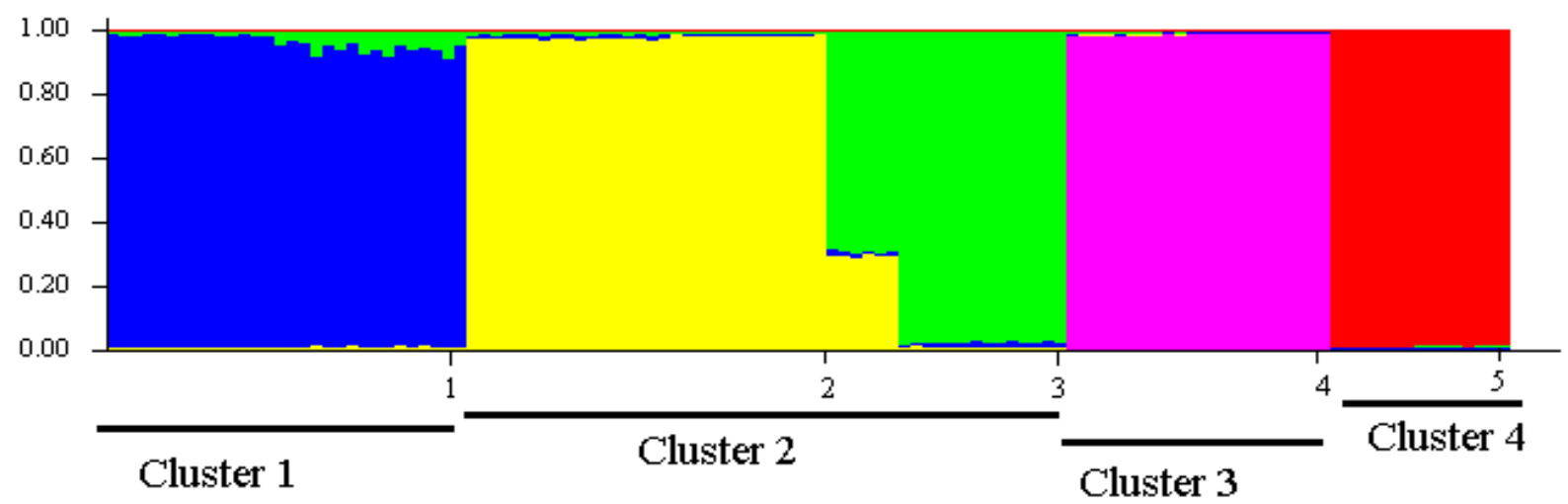

Figure. 7) Population structure of five P.canius populations in Malaysia.

452 Population assignment outcomes evidently revealed that almost all individuals were assigned to 453 their original populations with the probability rate of $\mathrm{P}>0.05$ (Table. 13). However, the 454 estimation of individual assignment to their populations with the same probabilities revealed the 455 closer rates in comparison levels to other sampling sites. For instance, the Negeri Sembilan 456 population had a relatively closer assignment ratio to the Selangor population. 
458

459

460

461

462

463

464

465

466

467

468

469

470

471

472

473

474

475

476

477

478

479

480

481

\begin{tabular}{|c|c|c|c|c|c|c|}
$\begin{array}{c}\text { Assigned } \\
\text { Population }\end{array}$ & CA\% & \multicolumn{5}{c|}{ Original Location } \\
\cline { 2 - 7 } & & $\begin{array}{c}\text { N.Sembilan } \\
\text { (N=30) }\end{array}$ & $\begin{array}{c}\text { Sabah } \\
\mathbf{( N = 3 0 )}\end{array}$ & $\begin{array}{c}\text { Selangor } \\
(\mathbf{N = 2 0})\end{array}$ & $\begin{array}{c}\text { Sarawak } \\
(\mathbf{N}=\mathbf{2 2})\end{array}$ & $\begin{array}{c}\text { Johor } \\
\mathbf{( N = 1 5 )}\end{array}$ \\
\hline N.Sembilan & 100 & 4.219 & 70.330 & 35.873 & 117.792 & 92.839 \\
\hline Sabah & 100 & 70.143 & 4.338 & 58.286 & 132.093 & 96.994 \\
\hline Selangor & 100 & 35.937 & 58.537 & 4.715 & 101.049 & 83.156 \\
\hline Sarawak & 100 & 115.433 & 129.921 & 98.626 & 3.133 & 101.070 \\
\hline Johor & 100 & 88.554 & 92.895 & 78.807 & 99.143 & 2.761 \\
\hline
\end{tabular}

Table. 13) Population assignment based upon five microsatellite loci frequencies in P.canius

(CA: correct assignment).

Analysis of population bottleneck did not identified substantiating signals of recent population drop in all populations studied using the two phase model (T.P.M) estimations (Table. 14). Furthermore, calculation of the infinite-allele model (I.A.M) comprehensively implied that there was no bottleneck evidence among the studied populations, while the parallel statement was assumed using the stepwise mutation model (S.M.M). Moreover, the shift-mode estimation of allele frequencies was perceived in all five populations, while altogether none of the mutation models were broadly illustrated consistent signals of bottleneck in engaged populations. Therefore, the current experiment could not detect any signals of bottleneck within the P.canius populations based on three applied models. Nevertheless, outcomes of mutational models consistently suggested the extension in populations due to absence of genetic drift and /or an invasive allele originating from different populations (Piry et al., 1999).

\begin{tabular}{|c|c|c|c|c|c|c|}
\hline & \multirow[t]{2}{*}{ I.A.M } & \multicolumn{3}{|c|}{ T.P.M } & \multirow[t]{2}{*}{ S.M.M } & \multirow[t]{2}{*}{ Mode Shift } \\
\hline & & 60 & 70 & 80 & & \\
\hline N.Sembilan & 0.22672 & 0.24435 & 0.26030 & 0.26596 & 0.28595 & Y \\
\hline Sabah & 0.07656 & 0.09247 & 0.09295 & 0.09683 & 0.10790 & Y \\
\hline Selangor & 0.28119 & 0.31416 & 0.34221 & 0.32656 & 0.64363 & Y \\
\hline Sarawak & 0.17976 & 0.21249 & 0.21558 & 0.20907 & 0.24057 & Y \\
\hline Johor & 0.18105 & 0.21600 & 0.24444 & 0.26510 & 0.22513 & Y \\
\hline
\end{tabular}

Table. 14) $P$ values originated from bottleneck analysis within five populations of P.canius (I.A.M: infinite allele model, T.P.M: two phase model, S.M.M: stepwise mutational model, estimation indicate the mutation in stepwise mutational model: Y: yes, N: no) (*Significant values $P<0.05)$. 


\section{DISCUSSION}

483 Phylogeography and Evolutionary History

484

485

486

487

488

489

490

491

492

493

494

495

496

497

498

499

500

501

502

503

504

505

506

507

508

509

510

511

512

This study has confirmed the efficiency of the COI barcode in identification of eel-tail catfish species. Barcoding fragment has been effectively sequenced mitochondrial DNA isolated from two species of family Plotosidae. Current study provided the first sequence database of P.canius to be submitted into barcoding data set. The first and the most common outcome of the undergone experiment could be the involvement of two common haplotype. While the most common sequence was KR086940 between populations of Selangor $(n=7)$, Sarawak $(n=6)$, and Johor $(n=9)$, the KR086939 identified as second common haplotype sharing between Johor $(n=$ 6) and Negeri Sembilan $(n=4)$. Nevertheless, the most significant finding should be the occurrence of shared haplotype between Selangor, Johor (Peninsular Malaysia) populations and the Sarawak (Borneo) population. The haplotype sharing and their consequent gene flow could practically happen due to several reasons such as breeding migration, mutation, pelagic larvae, and sharing of common ancestors (Frankham, 1996).

Migration is a common behaviour in nearly 3\% of all extant fish species (Binder et al., 2011). However, there is practically no record on migration and migratory behaviour of family Plotosidae, thus the first assumption of dispersal via migration and ocean current might be highly unlikely since majority of the catfish species cannot endure long distance swimming (more than 500 kilometers) due to their body shape and structure (Jónsson, 1982). In addition, marine dispersal of eggs, larvae and even juveniles of P.canius between two separate ocean currents comprising Straits of Malacca (Selangor and Johor) and South China Sea currents (Sarawak) might also be questionable. In the Strait of Melaka, circulation of currents (particularly in surface) are due to effects of tidal patterns and wind, while the route of both surface and deep layer currents are shown to be relatively the same and toward northwest (Rizal et al., 2010). In Johor, however, currents are highly depend on strong winds during monsoon seasons. Indeed, if the monsoon is in its northeast route, the current streams toward South along the coastal region of Malaysia, otherwise, the current will be northward (Mohd Fadzil \& Chuen, 2011). Finally, pattern of ocean currents in western South China Sea are largely influenced by season. The circulation in South segment of western current tends to be stable and northward where after separation from coastal region, it forms a northeastern pattern in summer. In fall, however, it 
513 strongly flows toward southwest (Fang et al., 2012). Therefore, general patterns of aquatic

514 circulation in Strait of Melaka, Johor maritime territory and western area of South China Sea

515 might not strongly implies the probable distribution of grey eel-tail catfish eggs, larvae and

516 juveniles and its consequent gene flow and genetic connectivity.

517 Considering all possible expectation on genetic variability and gene flow of P.canius in

518 Peninsular Malaysia, the second hypothesis of sharing common ancestor due to historical

519 geographic events may reflect the most plausible explanation. Southeast Asia is believed to 520 endured simultaneous glaciation and consequent deglaciation along with its associated 521 decreasing and increasing of marine levels during the Pleistocene period which greatly 522 influenced continental and oceanic configuration (Voris, 2000). During such variations, some 523 regions might be preserved their stable environmental conditions that is nowadays called a 524 refugium on which can greatly affect the gene flow and genetic variability particularly in 525 endemic species (Hobbs et al., 2013). Moreover, geographical information proposed that the 526 Pacific and Indian ocean were initially connected directly before the formation of Sundaland 527 (nowadays submerged forming shallow ocean of most Southeast Asia with less than 100m depth) 528 during the Triassic up to the Pleistocene period (Esa et al., 2008), hence made such gene flow 529 possible between these comparatively distant locations.

530 Demographic history analyses did not found any evidence of recent population expansion in all 531 P.canius populations. Thus, the evolutionary history estimation (the point of expansion) could 532 not be estimated but the P.canius populations were regarded as being in a stable state, possibly 533 for a long period of time. Nevertheless, comparison of $\theta_{1}$ and $\theta_{0}$ parameters for all populations 534 indicates a relatively slow growth rate in female populations of P.canius except in the Sabah 535 population.

540 Overall allelic richness revealed quite lower rates using the cross amplified primers ranging from $5412-8$ among the sampled populations in comparison with original species (Rourke et al., 2010). 542 Tan 3-28 demonstrated the highest overall allelic rate fluctuating from 1-3 among five 543 populations of P.canius, while the lowest level was detected in Tan 3-27. Moreover, the Selangor 544 population showed maximum number of alleles (9), whereas the Johor and Sarawak populations 
545 exhibited the lowest (6). Similar instance of low allelic variation have been described in

546 Bolbometopon muricatum (Priest et al., 2014), Schizothorax biddulphi (Palti et al., 2012) and

547 Prosopium cylindraceum (Mccracken et al., 2014). A possible reason for the occurring of low

548 levels of allelic richness might be due to the small employed population size. Hale et al. (2012)

549 pointed out the positive effects of sampling size between 25 to 30 individuals per population,

550 however they also mentioned the necessity of 5-100 samples per collection to avoid rare

551 uninformative alleles. Marine vertebrates are believed to present greater allele difference at their

552 microsatellite primers comparing to freshwater populations, which is mostly consistent with their

553 higher population evolutionary size (Neff \& Gross, 2001). Their research later revealed that the

554 difference in microsatellite polymorphism among classes and species could be highly dependent

555 upon changes in life history and population biology and moderately to differences happening to

556 microsatellite functions during natural selection. Therefore, the fewer number of allele found in

557 P.canius might be due to variation in its biology and historic traits, however, the correlation of

558 allelic richness and sample size should not be overlooked.

559 The average value of observed heterozygosity $\left(H_{O}\right)$ estimated in the five tested microsatellites in

560 P.canius were as low as 0.2168 , which showed high difference levels in comparison to standard

561 heterozygosity in marine populations $\left(H_{O}=0.79\right)$ and anadromous fish species $\left(H_{O}=0.68\right)$

562 (DeWoody \& Avise, 2000). In fact, considerable heterozygote deficiencies were observed in the

563 engaged populations with the exception of the Tan 1-7 and Tan 3-28 loci. Similar temporal

564 pattern of low genetic diversity have been reported for Pleuronectes platessa in Island (Hoarau et

565 al., 2005) and Clarias macrocephalous(Na.Nakorn et al., 1999), while in most catfish species

566 higher levels of heterozygosity have been documented as in Mystus nemurus $\left(H_{o}=0.44-0.57\right)$

567 (Usmani et al. 2003). Several decisive issues might influence the genetic variability of marine

568 species through the variation of Hardy-Weinberg including migration, genetic drift, sample size,

569 over-exploitation, effective size of population and patterns of mating (DeWoody \& Avise, 2000).

570 Certainly, P.canius should not be presumably considered as long distance migratory marine fish

571 species due to its body structure (Riede, 2004). Alternatively, a possibility of genetic drift in the

572 current study is also suspicious as it basically happens only in small effective size populations

573 that experiencing a period of bottleneck (DeWoody \& Avise 2000) at which is completely

574 invalidated in marine species studies like current research. 
576 Small sample size of collected populations might also be measured as a major parameter in

577 detection of low heterozygosity variation because of the failure to accurately detect the entire

578 extant alleles of the selected populations, hence, deficiency in heterozygote identification

579 (Na·Nakorn et al., 1999). Indeed, the current collection size for P.canius used for population

580 genetic analysis purposes should be quite small based on Kalinowski (2005), therefore, the

581 hypothesis of deficiency in heterozygote detection due to the low level of sampled specimen

582 could be accepted. The last cause of a low heterozygosity levels and its consequent genetic

583 variation is non-random system of mating behaviour among populations (Brook et al., 2002;

584 Balloux et al., 2004). Estimation of HWD for the current study however, showed considerable 585 deviation for approximately $36 \%$ of the primer/population pairs, which might be due to 586 heterozygote deficiency effects. However, Balloux et al. (2004) highlighted that the positive 587 correlation of inbreeding and heterozygosity needs to be examined through application of more 588 polymorphic markers on which demonstrates greater proportion of linkage disequilibrium. 589 Alternatively, the correlation of Fis values and inbreeding have been practically assessed and 590 documented in many studies (Balloux et al., 2004; Abdul-Muneer, 2005; O’Leary et al., 2013).

591 The positive calculated estimations could be translated as a decrease in heterozygous levels 592 among offspring in a population, mostly due to absence of random mating and its subsequent 593 inbreeding. The current study showed considerable significance levels $(\mathrm{P}<0.05)$ of Fis 594 estimations. This alongside with substantial departure from HWE would indicate the damaging 595 effect of heterozygosity deficit within the populations.

599 A remarkably high levels of genetic structure were detected among populations of $P$. canius 600 ranging from 0.05417 to 0.62504 , showing significantly high structuring among studied 601 populations except differences between Johor - Selangor samples $\left(F_{S T}=0.05417\right)$ and Selangor 602 Negeri Sembilan $\left(F_{S T}=0.09806\right)$. Moreover, AMOVA statistics evidently revealed that 603 approximately $64 \%$ of genetic variations were due to within population variations. Hence, the 604 fairly high $F_{S T}$ rates, significant hierarchical molecular results and consequent higher genetic 605 variances among P.canius populations in Peninsular Malaysia and their relatives in Borneo, in 
606 addition to the detection of only one sharing haplotype (KR086940), would suggest the absence 607 of contemporary gene flow among them most probably due to the geological modification, 608 consequential rise in marine water levels and historical continental separation during the 609 Pleistocene era (Esa et al., 2008; Song, 2012). However, exceptional cases between Selangor 610 Negeri Sembilan and Selangor - Johor might be inversely interpreted as occurrence of gene flow 611 or migration regarding to fairly close distances rather than extraordinary distance between 612 Borneo and Peninsular Malaysia. The sequential genetic diversity presented in this study could 613 be caused by high haplotype frequencies among the five populations of P.canius in Malaysia, in 614 addition to identification of unique sequences in each population (except in Johor). The present 615 patterns of differentiation among catchments is believed to be significantly as a consequence of 616 the Pleistocene associated historical and geological continental and sea level distraction and its 617 subsequent isolation of lands and populations (Esa et al., 2008).

618 The calculated $F_{S T}$ values of five microsatellites in P.canius showed significant estimation, 619 indicating substantial genetic structure and differentiation among the studied populations. All 620 populations also showed significantly high assignment rates, followed by a low membership 621 recorded for other population clusters. High rates of proper assignment might indicates strong 622 population differentiation among the studied populations (Paetkau et al., 2004). Although the 623 Sabah population demonstrated a close pairwise distance with the Selangor and Negeri Sembilan 624 populations, the Negeri Sembilan and Selangor populations showed the lowest differentiation 625 level (0.29711), and also the highest cluster membership in comparison with other populations. 626 Surprisingly, the highest level of pairwise Fst differentiation has been estimated between the 627 Johor population and the other four populations, in contrast to the closer geographical distance 628 between the Johor and the Negeri Sembilan populations. Indeed, microsatellite analysis made a 629 relatively counter-outcome in comparison with mitochondrial results, where $F_{S T}$ estimation of 630 former populations was estimated as the lowest among the P.canius samples. Discrepancies 631 between genetic differentiation detection through microsatellite loci and mitochondrial DNA is 632 believed to be related to three factors: (1) high sensibility of mitochondrial COI gene in detection 633 of variation (Shaw et al. 2004), (2) weaker nuclear-based subpopulation detection (Cano et al. 634 2008) and (3) technical complications of microsatellite like homoplasy (Estoup et al., 2002). 
636 One of the most common practical problems, which is believed to be mostly associated with 637 microsatellite primers (due to higher mutation rate) is well-known as homoplasy (Balloux \& 638 Lugon-Moulin, 2002). Homoplasy might diminish the microsatellite-based population 639 differentiation signals. The existence of homoplasy is highly dependent on the occurrence of 640 different identical locus copies, while such identical character is not consequent of mutual 641 ancestor. In fact, the occurrence of homoplasy might be correlated with combination effects of 642 high rates of mutation, and outsized population together with strong restriction in allele size 643 (Estoup et al., 2002). However, the effective number of alleles on which presented in Table. 8 644 and Table. 9 showed a low level of allele size frequency, the current population size of P.canius 645 used for population genetic analysis is ostensibly quite small based on Kalinowski (2005) rather 646 than being oversized. Hence, the later effective cause of homoplasy is somehow nullified in this 647 study. Furthermore, several microsatellite based studies have pointed out the significance of 648 Stepwise Mutation Model (S.M.M) on possibility of homoplasy in different taxa (Angers \& 649 Bernatchez, 1997; Culver et al., 2001; Estoup et al., 2002; Anmarkrud et al., 2008), which was 650 invalidated by provided statistics on bottleneck analysis of recent study in Table.14.

651 O'Reilly et al. (2004) later pointed out that implications of homoplasy in identification of 652 population structure using microsatellite loci are supposedly common in marine species. 653 Nevertheless, further researches have been implied that implications of genetic drift and gene migration might have considerably greater effects on population differentiation analysis in comparison with homoplasy (Estoup et al., 2002). Basically, marine vertebrates supposed to have the higher population effective size $\left(N_{e}\right)$ comparing to freshwater species (Hauser \& 657 Carvalho, 2008). Besides, genetic drift and effective size are believed to be greatly correlated, 658 hence it is highly probable that neighbouring geographical populations demonstrate the 659 imperceptible population differentiation and structures especially using neutral primers like 660 microsatellites (Larmuseau et al., 2010).

661

662

663

664

665

666

667

668

669 
670

671

672

673

674

675

676

677

678

679

680

681

682

683

684

685

686

687

688

689

690

691

692

693

694

695

696

697

698

699

700

701

\section{CONCLUSION}

The current genetic characterization of P.canius provided some basic results on their phylogeny and population structure. The phylogenetic and phylogeographic analysis of P.canius noticeably constructed accurate clusters in the five population of Malaysia, demonstrating the capability of the chosen mitochondrial COI barcoding gene to potentially assign the genus Plotosus into their biological taxa. Indeed, COI analysis resolved the phylogenetic relationships between P.lineatus and P.canius populations, supporting their taxonomic status as different species. A low mitochondrial differentiation was found among P.canius populations with some indication of endemism (haplotype restricted only to a particular population) as observed in the Sabah population. Nevertheless, the COI gene revealed sufficient informative interpretation of relationships among the five populations, supporting by reasonable bootstrapping values ( $>85 \%)$.

The sharing of haplotypes between a few samples from Peninsular Malaysia and their Sarawak counterpart of Borneo showed the sensitivity of the COI marker to infer the biogeographical history of $P$. canius and potentially other marine taxa in the region.

Microsatellites analyses on the population structure of P.canius showed slightly different patterns of structuring in comparison with the COI findings. Nevertheless, both markers detected higher level of among population differentiations than within population variability. In addition, four main clusters or genetic stocks of P.canius were identified using the cross species amplification study of $T$. tandanus microsatellites.

Finally, the results from this study has provided valuable understandings on the genetic characterization, molecular phylogeny, evolutionary kinship, and population structuring of P.canius, in particular, and the genus Plotosus, in general. However, further studies must be conducted using more geographical and sampling sites, larger population sizes per site. Furthermore, designing species specific hypervariable nuclear markers such as microsatellite for P.canius must be considered in order to accurately analyze the population structure and genetic diversity of P.canius before implementation of advanced fisheries and conservation strategies. 
702

703

704

705

706

707

708

709

710

711

712

713

714

715

716

717

718

719

720

\section{REFERENCES}

Abdul-Muneer, P.M. (2005). Molecular genetic characterization of endemic yellow catfish, Horabagrus brachysoma (Gunther). Cochin University of Science and Technology. 238 pp.

Angers, B., Bernatchez, L. (1997). Complex evolution of a salmonid microsatellite locus and its consequences in inferring allelic divergence from size information. Molecular Biology and Evolution 14(3), 230 - 238.

Anmarkrud, J.A., Kleven, O., Bachmann, L., Lifjeld, J.T. (2008).Microsatellite evolution: Mutations, sequence variation, and homoplasy in the hypervariable avian microsatellite locus HrU10. BMC Evolutionary Biology 8(1), 1-10.

Appeltans, W., Ahyong, S.T, Anderson, G., Angel, M.V., Artois, T., Bailly, N., Costello, M. J. (2012). The magnitude of global marine species diversity. Current Biology 22(23), 2189-2202.

Balloux, F., Amos, W., Coulson, T. (2004). Does heterozygosity estimate inbreeding in real populations? Molecular Ecology 13(10), 3021-3031.

Balloux, F., Lugon-Moulin, N. (2002). The estimation of population differentiation with microsatellite markers. Molecular ecology 11(2), 155-65.

Bandelt, H., Forster, P., Röhl, A. (1994). Median-Joining Networks for Inferring Intraspecific Phylogenies. Molecuar Biology and Evolution 16(1), 37-48.

Binder, T.R., Cooke, S.J., Hinch, S.G. (2011). The Biology of Fish Migration.In "Encyclopedia of Fish Physiology: From Genome to Environment", Academic Press, San Diego. pp 1921-1927.

Botstein, D., White, R.L., Skolnick, M., Davis, R.W. (1980). Construction of a genetic linkage map in man using restriction fragment length polymorphisms. American Journal of Human Genetics 32(3), 317-341.

Bourlat, S.J., Borja, A., Gilbert, J., Taylor, M.I., Davies, N., Weisberg, S.B., Obst, M. (2013). Genomics in marine monitoring: New opportunities for assessing marine health status. Marine Pollution Bulletin 74(1), 19-31. 
Brook, B., Tonkyn D, O’Grady J, Frankham R. (2002). Contribution of inbreeding to extinction risk in threatened species. Consevation Ecology 6 (1):16 [online].

Butchart, S., Baillie, J., Chenery, A., Collen, B., Gregory, R., Revenga, C., Walpole, M. (2010). Global Biodiversity: Indicators of Recent Declines. Science 328(5982), 1164-1168.

Cano, J., Mäkinen, H., Merilä, J. (2008). Genetic evidence for male-biased dispersal in the three-spined stickleback (Gasterosteus aculeatus). Methods in Ecology 16 (14), 3234-3242.

Carpenter, K.E. (1999). The Living Marine Resource of Western Central Pacific. Volume4: Bony Fishes (Mugilidae-Carangidae). (Carpenter, K.E. and Niem, V.H., Eds.) (Vol. 3), FAO, Rome.

Charlesworth, D., Willis, J. (2009). The genetics of inbreeding depression. Nature Reviews Genetic 10(11), 783-796.

Collette, B.B., Carpenter, K. E., Polidoro, B.A., Boustany, A., Die, D.J., Elfes, C., Nelson, R. (2011). High Value and Long Life - Double Jeopardy for Tunas and Billfishes. Science 333(6040), 291-292.

Costello, AB., Down TE, Pollard SM, Pacas CJ, Taylor EB. (2003). The influence of history and contemporary stream hydrology on the evolution of genetic diversity within species: an examination of microsatellite DNA variation in bull trout, Salvelinus confluentus (Pisces: Salmonidae). Evolution; international journal of organic evolution 57(2), 328-344.

Culver, M., Menotti-Raymond, M.A., O'Brien, S. J. (2001). Patterns of Size Homoplasy at 10 Microsatellite Loci in Pumas (Puma concolor). Molecular Biology and Evolution 18 (6), 1151-1156.

DeWoody, J. A., Avise, J.C. (2000). Microsatellite variation in marine, freshwater and anadromous fishes compared with other animals. Journal of Fish Biology 56(3), 461-473.

Duvernell, D., Lindmeier J, Faust K, Whitehead A. (2008). Relative influences of historical and contemporary forces shaping the distribution of genetic variation in the Atlantic killifish, Fundulus heteroclitus. Molecular Ecology 17(5), 1344-1360.

Esa, Y., Sirajm S., Daud, S. (2008). Mitochondrial DNA diversity of Tor tambroides Valenciennes (Cyprinidae) from five natural populations in Malaysia. Zoological studies 3(47), 360-367. 
753

754

755

756

757

758

759

760

761

762

763

764

765

766

767

768

769

770

771

772

773

774

775

776

Estoup, A., Jarne, P., Cornuet, J.M. (2002). Homoplasy and mutation model at microsatellite loci and their consequences for population genetics analysis. Molecular Ecology 11(9), 1591-1604.

Evanno, G., Regnaut, S., Goudet, J. (2005). Detecting the number of clusters of individuals using the software STRUCTURE: A simulation study. Molecular Ecology 14(8), 2611-2620.

Excoffier, L., Laval, G., Schneider, S. (2005). Arlequin (version 3.0): an integrated software package for population genetics data analysis. Evoltionary Bioinformatics Online 1, 47-50.

Fang, G., Wang, G., Fang, Y., Fang, W. (2012). A review on the South China Sea western boundary current. Acta Oceanologica Sinica 31(5), 1-10.

Frankham, R. (1996). Relationship of Genetic Variation to Population Size in Wildlife. Conservation Biology 10(6), 1500-1508.

Froese, R., Pauly, D. (2015). FishBase. World Wide Web electronic publication.

Fu, Y. X. (1997). Statistical tests of neutrality of mutations against population growth, hitchhiking and background selection. Genetics 147(2), 915-925.

Glaubitz, J.C. (2004). CONVERT: A user-friendly program to reformat diploid genotypic data for commonly used population genetic software packages. Molecular Ecology Notes 4(2), 309-310.

Goudet, J. (1995). FSTAT (Version 1.2): A Computer Program to Calculate F-Statistics. Journal of HERIDITY 86(6), 485-486.

Gutiérrez, J.P., Royo, L.J., Álvarez, I., Goyache, F. (2005). MolKin v2.0: a computer program for genetic analysis of populations using molecular coancestry information. Journal of Heredity 96, 718-721.

Hale, M.L., Burg, T.M., Steeves, T.E. (2012). Sampling for Microsatellite-Based Population Genetic Studies: 25 to 30 Individuals per Population Is Enough to Accurately Estimate Allele Frequencies. PLoS ONE 7(9), 1-12.

Hall, T. (1999). BioEdit: a user-friendly biological sequence alignment editor and analysis program for Windows 95/98/NT. Nucleic Acids Symposium Series 41(1999), 91-98. 
Hauser, L., Carvalho, G. (2008). Paradigm shifts in marine fisheries genetics: ugly hypotheses slain by beautiful facts. Fish and Fisheries 9(4), 333-362.

Hoarau, G., Boon E, Jongma DN, Ferber S, Palsson J, Van der Veer HW, .. Olsen JL. (2005). Low effective population size and evidence for inbreeding in an overexploited flatfish, plaice (Pleuronectes platessa L.). Proceedings. Biological sciences / The Royal Society 272(1562), 497503.

Hobbs, J.P.A., Herwerden, V., Jerry, D.R., Jones, G.P., Munday, P.L. (2013). High genetic diversity in geographically remote populations of endemic and widespread coral reef angelfishes (genus: Centropyge). Diversity 5(1), 39-50.

Hoffmann, M., Hilton-Taylor, C., Angulo, A., Böhm, M., Brooks, T. M., Butchart, S.H.M., Stuart, S.N. (2011). The impact of conservation on the status of the world's vertebrates. Science 330(6010), 1503-1509.

Jónsson, G. (1982). Contribution to the Biology of Catfish (Anarhichas lupus) at Iceland. Journal of Marine Research Institute 6 (4), 3-26.

Kalinowski, S.T. (2005). Do polymorphic loci require large sample sizes to estimate genetic distances? Journal of Heredity 94, 33-36.

Khan, M.S.A., Alam, M.J., Rheman, S., Mondal, S., Rahman, M.M. (2002). Study on the Fecundity and GIS of Brackish Catfish Plotosus canius. Online Journal of Biological Sciences 4(2), 232-234.

Krishnamurthy, P.K., Francis, R. (2012). A critical review on the utility of DNA barcoding in biodiversity conservation. Biodiversity and Conservation 21(8), 1901-1919.

Kumar, B. (2012). Finding of ( Plotosidae: Siluriforms ) and its Abundance from Parangipettai Coastal Area - A Review. International Journal of Recent Scientific Research 3(6), 482-485.

Larmuseau, M.H.D., Raeymaekers JAM, Hellemans B, Van Houdt JKJ, Volckaert FAM. (2010). Mitonuclear discordance in the degree of population differentiation in a marine goby. Journal of Heredity 105(6), 532-542. 
802 Leffler, E.M., Bullaughey, K., Matute, D.R., Meyer, W.K., Ségurel, L., Venkat, A., Przeworski, M.

803 (2012). Revisiting an Old Riddle: What Determines Genetic Diversity Levels within Species? PLoS $804 \quad$ Biology 10(9), e1001388.

805 Leh, M.U.C., Sasekumar, A., Chew, L.L. (2012). Feeding biology of Eel Catfish Plotosus Canius 806 Hamilton in a Malaysian Mangrove Estuary and Mudflat. Raffles Bulletin of Zoology 60(2), 551$807 \quad 557$.

808

809

810

Leray, M., Knowlton, N. (2015). DNA barcoding and metabarcoding of standardized samples reveal patterns of marine benthic diversity. Proceedings of the National Academy of Sciences 112(7), 20762081.

Librado, P., Rozas, J. (2009). DnaSP v5: A software for comprehensive analysis of DNA polymorphism data. Bioinformatics 25(11), 1451-1452.

Mccracken, G.R., Wilson KL, Brewis HT, Mcbride MC, Paterson I, Perry R. (2014). Development of 26 novel microsatellite makers for the round whitefish ( Prosopium cylindraceum) and successful polymorphic cross-specific amplification of seven previously developed salmonid markers. Conservation Genetic Resources 6(4), 1023-1026.

Magurran, A.E., Baillie, S.R., Buckland, S.T., Dick, J.M., Elston, D.A.., Scottm E,M,, Wattm A,D, (2010), Long-term datasets in biodiversity research and monitoring: Assessing change in ecological communities through time. Trends in Ecology and Evolution 25(10), 574-582.

Mohd Fadzil Mohd Akhir, Chuen, Y.J. (2011). Seasonal Variation of Water Characteristics during InterMonsoon along the East Coast of Johor . Journal of Sustainability Science and Management 6(2), 206-214.

Na.Nakorn, U., Taniguchi N, Nugroho E, Seki S, Kamonrat W. (1999). Isolation and characterization of microsatellite loci of Clarias macrocephalus and their application to genetic diversity srudy. Fisheries Science 65(4), 520-526.

Neff, B.D., Gross, M.R. (2001). Microsatellite evolution in vertebrates: inference from AC dinucleotide repeats. Evolution; international journal of organic evolution 55(9), 1717-1733. 
828

829

830

831

832

833

834

835

836

837

838

839

840

841

842

843

844

845

846

847

848

849

850

851

852

O'Leary, S.J., Hice LA, Feldheim KA., Frisk MG, McElroy AE, Fast MD, Chapman DD. (2013). Severe Inbreeding and Small Effective Number of Breeders in a Formerly Abundant Marine Fish. PLoS ONE 8(6), 2-9.

O'Reilly, P.T., Canino MF, Bailey KM, Bentzen P. (2004). Inverse relationship between F ST and microsatellite polymorphism in the marine fish, walleye pollock (Theragra chalcogramma): Implications for resolving weak population structure. Molecular Ecology 13(7), 1799-1814.

Paetkau, D., Slade R, Burden M, Estoup A. (2004). Genetic assignment methods for the direct, real-time estimation of migration rate: a simulation-based exploration of accuracy and power. Molecular Ecology 13(1), 55-65.

Palti, Y., Luo A, Charlet GG, Hu Y. (2012). A Second Generation Integrated Map of the Rainbow trout (Oncorhynchus mykiss) Genome: Analysis of Conserved Synteny with Model Fsh Genomes. Marine Biotechnology 14(3), 343-357.

Pauly, D., Christensen, V., Guénette, S., Pitcher, T.J., Sumaila ,U.R., Walters, C.J., Zeller, D. (2002). Towards sustainability in world fisheries. Nature 418(6898), 689-695.

Peakall, R., Smouse, P.E. (2012). GenALEx 6.5: Genetic analysis in Excel. Population genetic software for teaching and research-an update. Bioinformatics 28(19), 2537-2539.

Pereira, H., Leadley P, Proença V, Alkemade R. (2010). Scenarios for global biodiversity in the 21st century. Science 330(6010), 1496-1501.

Piry, S., Alapetite A, Cornuet JM, Paetkau D, Baudouin L, Estoup A. (2004). GENECLASS2: A software for genetic assignment and first-generation migrant detection. Journal of Heredity 95(6), pp.536539.

Piry, S., Luikart, G., Cornuet, J.-M. (1999). BOTTLENECK: A computer program for detecting recent reductions in the effective population size using allele frequency data. Journal of Heredity 90(4),502-503. 
853

854

855

856

857

858

859

860

861

862

863

864

865

866

867

868

869

870

871

872

873

874

875

876

Priest, M.A., Almany GR, Braun CD, Hamilton RJ, Lozano-cortés DF, Saenz-agudelo P, Berumen ML. (2014). Isolation and characterization of 29 microsatellite markers for the bumphead parrotfish, Bolbometopon muricatum, and cross amplification in 12 related species. Marine Biodiversity 44(4), $1-6$.

Primack, R. (2002). Essential of conservation genetics 3rd ed., Sunderland, MA: Sinauer Association Inc.603.pp.

Pritchard, J.K., Stephens, M., Donnelly, P. (2000). Inference of population structure using multilocus genotype data. Genetics 155(2), 945-959.

Prithiviraj, N. (2014). Studies on Biological Properties and in Silico Approach of Plotosus canius, from Parangipettai Coastal Waters. International Journal of Modern Research Reviews 1(6), 24-37.

Prithiviraj, N., Annadurai, D. (2012). Studies on Bioactive Properties of the Catfish Plotosus canius (Hamilton , 1822). International Journal of Recent Scientific Research 3(6), 467-473.

Rice, W.R. (1989). Analyzing Tables of Statistical Tests. Evolution 43(1),223-225.

Riede, K. (2004). Global Register of Migratory Species - from Global to Regional Scales. Final Report of the R\&D-Projekt 80805 081, Federal Agency for Nature Conservation, Bonn, Germany.

Rizal, S., Setiawan, I., Iskandar, T., Ilhamsyam, Y., Musman, M., Whahid, M. (2010). Currents Simulation in the Malacca Straits by Using Three-Dimensional Numerical Model. Sains Malaysiana 39(4), 519-524.

Rogers, A. R., \& Harpending, H. (1992). Population growth makes waves in the distribution of pairwise genetic differences. Molecular biology and evolution 9(3), 552-569.

Rourke, M., Gilligan, D. (2010). Population Genetic Structure of Freshwater Catfish (Tandanus Tandanus) in the Murray-Darling Basin and Coastal Catchments of New South Wales: Implications for Future Re-stocking, Final report to the NSW Recreational Freshwater Fishing Trust for Project No. DPIFT48. Industry \& Investment - Fisheries Final Report Series No. 123. 73pp. 
877

878

879

880

881

882

883

884

885

886

887

888

889

890

891

892

893

894

895

896

897

898

899

900

Rourke, M.L., Teske PR, Attard CRM, Gilligan DM, Beheregaray LB, Rourke ML, Gilligan DM. (2010). Isolation and characterisation of microsatellite loci in the Australian freshwater catfish ( Tandanus tandanus ) Murray - Darling Basin. Conservation Genetic Resources 2(1), 245-248.

Rousset, F. (2008). GENEPOP'007: A complete re-implementation of the GENEPOP software for Windows and Linux. Molecular Ecology Resources 8(1), 103-106.

Shaw, P., Arkhipkin, A., Al-Khairulla, H. (2004). Genetic structuring of Patagonian toothfish populations in the Southwest Atlantic Ocean: the effect of the Antarctic Polar Front and deep-water troughs as barriers to genetic exchange. Molecular Ecologgy 13(11), 3293-3303.

Song, L.M. (2012). Understanding Divergence in Channa satiata: A Genetic and Morphological Approach. Master Thesis. University of Malaya, Kuala Lumpur, Malaysia.

Tajima, F. (1989). Statistical method for testing the neutral mutation hypothesis by DNA polymorphism. Genetics 123(3), 585-595.

Tallmon, D. A., Luikart, G., Waples, R.S. (2004). The alluring simplicity and complex reality of genetic rescue. Trends in Ecology and Evolution 19(9), 489-496.

Tamura, K., Nei, M. (1993). Estimation of the number of nucleotide substitutions in the control region of mitochondrial DNA in humans and chimpanzees. Molecular Biology and Evolution 10(3), 512-526.

Tamura, K., Stecher, G., Peterson, D., Filipski, A., Kumar, S. (2013). MEGA6: Molecular evolutionary genetics analysis version 6.0. Molecular Biology and Evolution 30(12), 2725-2729.

Thompson, J.D., Gibson, T. J., Plewniak, F., Jeanmougin, F., Higgins, D.G. (1997). The CLUSTAL X windows interface: Flexible strategies for multiple sequence alignment aided by quality analysis tools. Nucleic Acids Research 25(24), 4876-4882.

Thomsen, P.F., Kielgast, J., Iversen, L. L., Møller, P.R., Rasmussen, M., Willerslev, E. (2012). Detection of a Diverse Marine Fish Fauna Using Environmental DNA from Seawater Samples. PLoS ONE 7(8), 1-9. 
901 Usman, B., Amin, S.M., Arshad, A., Rahman, M. (2013). Review of Some Biological Aspects and 902 Fisheries of Grey-Eel Catfish Plotosus canius (Hamilton, 1822). Asian Journal of Animal and 903 Veterinary Advances 2(8), 154-167.

904 Usmani, S., Tan SG, Siraj SS, Yusoff K. (2003). Population structure of the Southeast Asian river catfish 905 Mystus nemurus. Animal Genetics 34(6),462-464.

906 Van Oosterhout, C., Hutchinson WF, Wills DPM, Shipley P. (2004). MICRO-CHECKER: Software for 907 identifying and correcting genotyping errors in microsatellite data. Molecular Ecology Notes $908 \quad 4(3), 535-538$.

909 Voris, H.K. (2000). Maps of Pleistocene sea levels in Southeast Asia: Shorelines, river systems and time 910 durations. Journal of Biogeography 27(5), 1153-1167.

911 Ward, R.D., Zemlak, T.S., Innes, B.H., Last, P.R., Hebert, P.D.N. (2005), DNA barcoding Australia's 912 fish species. Philosophical Transactions of the Royal Society of London. Series B, Biological Sciences 360(1462), 1847-57.

914 Wright, L.I., Tregenza, T. \& Hosken, D.J. (2008). Inbreeding, inbreeding depression and extinction. 915 Conservation Genetics 9(4), 833-843.

916 Zhang, A.B., He, L.J., Crozier, R.H., Muster, C., Zhu, C.D. (2010). Estimating sample sizes for DNA 917 barcoding. Molecular Phylogenetic and Evolution 54(3), 1035-1039.

918 Zhang, D.X., Hewittm G,M, (1996), Nuclear integrations: challenges for mitochondrial DNA markers. 919 Trends Ecology \& Evolution 11(6), 247-251. 